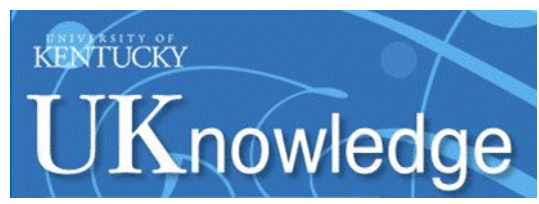

University of Kentucky

UKnowledge

\title{
EVALUATION OF CREATED WETLANDS AS AMPHIBIAN HABITAT ON A REFORESTED SURFACE MINE
}

\author{
Michaela M. Lambert \\ University of Kentucky, michaela.lambert@uky.edu \\ Digital Object Identifier: https://doi.org/10.13023/etd.2020.181
}

Right click to open a feedback form in a new tab to let us know how this document benefits you.

\begin{abstract}
Recommended Citation
Lambert, Michaela M., "EVALUATION OF CREATED WETLANDS AS AMPHIBIAN HABITAT ON A REFORESTED SURFACE MINE" (2020). Theses and Dissertations--Forestry and Natural Resources. 55. https://uknowledge.uky.edu/forestry_etds/55
\end{abstract}

This Master's Thesis is brought to you for free and open access by the Forestry and Natural Resources at UKnowledge. It has been accepted for inclusion in Theses and Dissertations--Forestry and Natural Resources by an authorized administrator of UKnowledge. For more information, please contact UKnowledge@lsv.uky.edu. 


\section{STUDENT AGREEMENT:}

I represent that my thesis or dissertation and abstract are my original work. Proper attribution has been given to all outside sources. I understand that I am solely responsible for obtaining any needed copyright permissions. I have obtained needed written permission statement(s) from the owner(s) of each third-party copyrighted matter to be included in my work, allowing electronic distribution (if such use is not permitted by the fair use doctrine) which will be submitted to UKnowledge as Additional File.

I hereby grant to The University of Kentucky and its agents the irrevocable, non-exclusive, and royalty-free license to archive and make accessible my work in whole or in part in all forms of media, now or hereafter known. I agree that the document mentioned above may be made available immediately for worldwide access unless an embargo applies.

I retain all other ownership rights to the copyright of my work. I also retain the right to use in future works (such as articles or books) all or part of my work. I understand that I am free to register the copyright to my work.

\section{REVIEW, APPROVAL AND ACCEPTANCE}

The document mentioned above has been reviewed and accepted by the student's advisor, on behalf of the advisory committee, and by the Director of Graduate Studies (DGS), on behalf of the program; we verify that this is the final, approved version of the student's thesis including all changes required by the advisory committee. The undersigned agree to abide by the statements above.

Michaela M. Lambert, Student

Dr. Christopher D. Barton, Major Professor

Dr. Steven J. Price, Director of Graduate Studies 


\title{
EVALUATION OF CREATED WETLANDS AS AMPHIBIAN HABITAT ON A REFORESTED SURFACE MINE
}

\author{
THESIS \\ A thesis submitted in partial fulfillment of the \\ requirements for the degree of Master of Science in \\ Forest and Natural Resource Sciences in the \\ College of Agriculture, Food and Environment \\ at the University of Kentucky
}

\author{
By \\ Michaela M. Lambert \\ Lexington, Kentucky \\ Co- Directors: Dr. Christopher Barton, Professor of Forest Hydrology and \\ Watershed Management \\ and Dr. Steven J. Price, Associate Professor of Stream and Riparian Ecology \\ Lexington, Kentucky \\ 2020
}

Copyright (C) Michaela M. Lambert 2020 


\title{
ABSTRACT OF THESIS \\ EVALUATION OF CREATED WETLANDS AS AMPHIBIAN HABITAT ON A REFORESTED SURFACE MINE
}

\begin{abstract}
Reclaimed mines often lack pre-mining habitat due to soil compaction and lack of natural features. If soils are de-compacted and natural features restored, new habitats can be created, such as wetlands for amphibians. It is important to understand which factors affect amphibian use of wetlands to estimate the efficacy of created wetlands as habitat. I sampled 40 wetlands among 4 ages $(2,4,6$, and 8 years) on a reforested surface mine to: 1$)$ characterize differences in wetland habitat across age classes, 2) estimate amphibian occupancy, 3) investigate estimated abundance of 4 amphibian species (Lithobates sylvaticus, L. clamitans, Notophthalmus viridescens, and Ambystoma maculatum) and 4) identify wetland characteristics most important for amphibian utilization of wetlands. Over 2,200 amphibian captures were recorded. There were 8 species found in 8 year-old wetlands, 5 in the 4 and 6 year-old wetlands, and 6 in the 2 year-old wetlands. Wetland age, specific conductance of water, vegetation cover, and canopy cover were predictors of amphibian occupancy and abundance. Water quality was better than described in streams affected by mining that exhibited limited amphibian occupancy and abundance. My results indicated that created wetlands on reforested surface mines provide suitable breeding habitat for pond breeding amphibians.
\end{abstract}

KEYWORDS: Reforestation, Created Wetland, Occupancy, Abundance, Amphibian

Michaela M. Lambert

(Name of Student)

05/15/2020

Date 


\title{
EVALUATION OF CREATED WETLANDS AS AMPHIBIAN HABITAT ON A REFORESTED SURFACE MINE
}

\author{
By \\ Michaela M. Lambert
}

Christopher D. Barton

Co-Director of Thesis

Steven J. Price

Co-Director of Thesis

Steven J. Price

Director of Graduate Studies

$05 / 15 / 2020$

Date 


\section{DEDICATION}

To Drs. Steven J. Price and Thomas G. Barnes, who opened the doors to the wildlife and natural resources fields for me. Thank you for showing me the importance of and the possibilities within the work that we do. 


\section{ACKNOWLEDGMENTS}

I would like to thank the U.S. Forest Service Monongahela National Forest, especially Anna Branduzzi and Todd Kuntz, as well as Thomas Skinner, and Kylie Schmidt for help in the field. I would also like to thank my committee members, Drs. Chris Barton, Steven Price, and John Cox, for the continuous support that they offered, as well as Wendy Leuenberger for help with stats and Allison Davis for help with ArcGIS. Research collection permits were provided by the West Virginia Division of Natural Resources (2018.208). Funding was provided by the University of Kentucky Graduate School, The University of Kentucky Department of Forestry and Natural Resources, The University of Kentucky Appalachian Center (Eller and Billings Research Award), The University of Kentucky College of Agriculture, Food, and Environment (Karri Casner Environmental Science Fellowship), and the Chicago Herpetological Society. Funding providers played no role in the formation of study design, data collection, data analysis and interpretation, writing of the report, and the decision to submit the article for publication. 


\section{TABLE OF CONTENTS}

ACKNOWLEDGMENTS

CHAPTER 1. EVALUATION OF CREATED WETLANDS AS AMPHIBIAN HABITAT ON A REFORESTED SURFACE

MINE

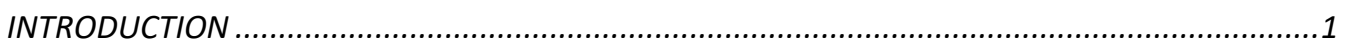

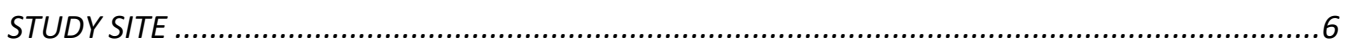

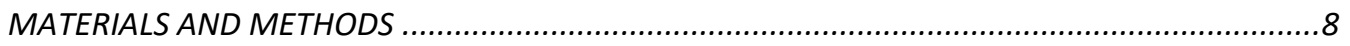

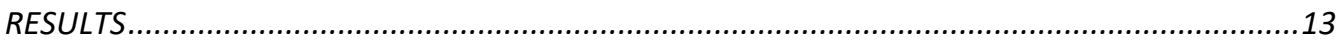

DISCUSSION

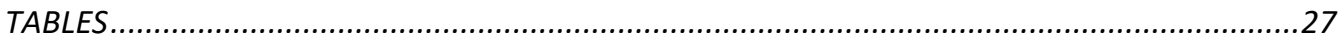

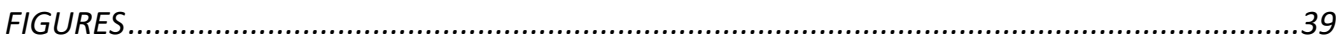

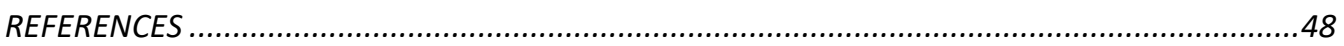

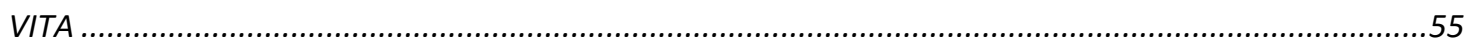




\section{LIST OF TABLES}

Table 1. Wetland Physical Parameter Ranges .............................................................. 27

Table 2. Wetland Physical Parameter ANOVA Results .................................................. 28

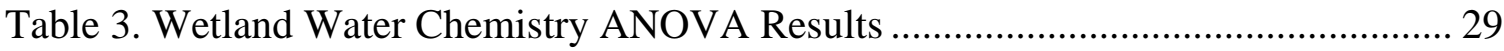

Table 4. Ambystoma maculatum Occupancy Models ................................................... 30

Table 5. Notophthalmus viridescens Occupancy Models ............................................ 31

Table 6. Lithobates clamitans Occupancy Models ......................................................... 32

Table 7. Lithobates sylvaticus Occupancy Models ....................................................... 33

Table 8. Pseudacris crucifer Occupancy Models ............................................................ 34

Table 9. Ambystoma maculatum Abundance Models.................................................... 35

Table 10. Notophthalmus viridescens Abundance Models........................................... 36

Table 11. Lithobates clamitans Abundance Models ...................................................... 37

Table 12. Lithobates sylvaticus Abundance Models................................................... 38 


\section{LIST OF FIGURES}

Figure 1. Ambystoma maculatum Occupancy and Mean Conductivity ........................... 39

Figure 2. Ambystoma maculatum Occupancy and Percent Vegetation Cover.................. 40

Figure 3. Notophthalmus viridescens Occupancy and Mean Conductivity ...................... 41

Figure 4. Lithobates clamitans Occupancy and Percent Vegetation Cover....................... 42

Figure 5. Pseudacris crucifer Occupancy and Mean Conductivity ................................. 43

Figure 6. Ambystoma maculatum Abundance and Mean Conductivity............................ 44

Figure 7. Notophthalmus viridescens Abundance and Percent Canopy Cover ................. 45

Figure 8. Lithobates sylvaticus Abundance and Mean Conductivity ............................... 46

Figure 9. 2018 Vs 20 Year Mean Precipitation ............................................................. 47 


\section{CHAPTER 1. EVALUATION OF CREATED WETLANDS AS AMPHIBIAN HABITAT ON A REFORESTED SURFACE MINE}

\section{INTRODUCTION}

Natural wetlands comprise just $6 \%$ of the earth's surface but are disproportionate in their function and biodiversity (Calhoun 2014, Gopal et al. 2000). Costanza et al. (1997) estimated the economic values of services provided by the world's freshwater ecosystems and found that, on a per-hectare basis, estuaries and freshwater floodplains/swamps were the world's two most valuable ecosystem types. Freshwater wetlands provide an estimated U.S. $\$ 4.8$ trillion per year in ecological services, compared to U.S. \$4.7 trillion per year in forests (Costanza et al. 1997). Wetland services include water storage, flood regulation, contaminant filtration and absorption, nutrient cycling, and critical habitat that supports a diversity of aquatic and terrestrial life (Costanza et al. 1997, Gopal et al. 2000, Woodward and Wui 2001, Zedler and Kercher 2005). However, wetlands worldwide have been drained for human uses including urban and agricultural purposes, disease management, and water transport (Batzer and Sharitz 2014, Dahl 2005, Dahl 2011). In the continental U.S. it was estimated that by the 1970s almost half of the wetlands had been filled or drained (Dahl 2005, Dahl 2011, Tiner 1984). To mitigate natural wetland loss, land managers began to construct wetlands (Batzer and Sharitz 2014, Dahl 2005, Dahl 2011). Between 1998 and 2004 there was a net gain of 98,014.86 freshwater wetland hectares (ha) in the United States, much of which can be attributed to the creation of over $283,279.95$ ha of created open water wetlands, most maintaining deep basins, steep slopes, and limited emergent vegetation. Without the contribution of open water wetlands, wetland gains would not have exceeded wetlands losses from 19982004 (Dahl 2005, Dahl 2011). More recently, ecologists have questioned the ability of 
created wetlands, which are often placed in disturbed landscapes, to provide the same services as natural wetlands (Calhoun 2014, Kudray and Schemm 2008). Studies have shown that created wetlands placed in degraded landscapes with deep basins and vegetation inhibited steep slopes, provide open water systems that often function differently than natural, vegetated wetlands (Minkin and Ladd 2003, Shulse et al. 2010). Because of this, the ability of created wetlands may be limited if adequate natural features, such as hydroperiod and vegetation cover, are not mimicked (Calhoun 2014, Denton and Richter 2013, Drayer and Richter 2016, Kross and Richter 2016, Porej and Hetherington 2005). However, if enough natural features can be mimicked, created wetlands may provide similar ecological functions to natural wetlands (Brodman et al 2006, Brown et al. 2012, Calhoun 2014, Dahl 2005, Drayer and Richter 2016, Kross and Richter 2016, Porej and Hetherington 2005, Semlitsch 2008, Shulse et al. 2010).

Surface mining is a common method of coal extraction in the mountains within the Appalachian region of the U.S. (Bernhardt and Palmer 2011). During surface mining, the land is stripped of vegetation, the top layers of soil and rock are removed, and the underlying coal seams are mined (Bernhardt and Palmer 2011). Mines are reclaimed according to the Surface Mining Control and Reclamation Act of 1977 (Public law 9587), often as non-native grasslands or forests (Bernhardt and Palmer 2011, Skousen et al. 2011, Surface Mining Control and Reclamation Act 1977). In this process the land is compacted to reduce erosion, restored to its original contour, and re-vegetated with native or non-native plants (Anderson et al. 1989, Plass 1982, Skousen et al. 2011, Surface Mining Control and Reclamation Act 1977). Ecological succession of plant communities on reclaimed mines is often arrested due to soil compaction (Franklin et al. 2012, Sena et 
al. 2015, Skousen et al. 2011, Zipper et al. 2011). De-compacting the soil and replacing non-native vegetation with native plants on these sites generates an opportunity to create habitats, such as upland wetlands and forests, for wildlife.

In an era of global biodiversity loss, amphibians have been recognized as one of the vertebrate taxa most threatened with population declines (Grant et al. 2016, Semlitsch et. al. 2017). Habitat loss and degradation has been identified as a major cause for declines in amphibians (Grant et al. 2016, Semlitsch et. al. 2017). Wetlands are particularly important for pond-breeding amphibians (Batzer and Sharitz 2014, Brown 2012). Wetlands offer a place for amphibians to breed that is usually devoid of large predators, such as fish, that can prey on both adults and larvae. In addition, the terrestrial habitat surrounding wetlands must also be sufficient to support adult amphibian populations and movement (Birx-Raybuck et al. 2010, Hamer et al. 2016, Marsh et al. 1999, Laan and Verboom 1990, Price et al. 2018, Semlitsch 2008, Shulse et al. 2010). Under sufficient conditions, pond-breeding amphibians have the ability to quickly recover loss of local populations because they can produce large clutch sizes and can disperse to neighboring wetlands (Gibbons et al. 2006, Hanski and Gilpin 1991, Semlitsch and Bodie 1998, Sjögren 1991). In areas where anthropogenic disturbance has led to pond-breeding amphibian declines, there is an opportunity to establish created wetlands with sufficient conditions to allow amphibian populations to rebound.

Surface mines present an opportunity to create high elevation wetland habitat for pond-breeding amphibians and other wildlife; however, previous studies have demonstrated reduced amphibian occupancy and abundance in natural streams affected by coal mining (Hutton et al. In Press, Muncy et al. 2014, Price et al. 2016). In one 
study, stream salamander occupancy and species richness were dramatically lower in streams affected by mining than in control streams (Muncy et al. 2014). In this study, specific conductance was 30 times greater, sulfate $\left(\mathrm{SO}_{4}\right)$ levels were 70 times greater, and concentrations of dissolved ions $(\mathrm{Ca}, \mathrm{Mg}, \mathrm{K}, \mathrm{Na})$ were greater in the streams affected by mining than in unmined forested control streams (Muncy et al. 2014). Price et al. (2016) also discovered reduced stream salamander occupancy and conditional abundance in streams affected by mining compared to reference reach streams. Another study showed that most stream salamander species and life stages exhibited reduced initial occupancy, colonization rates, persistence rates, and conditional abundance in mining affected streams over a three years monitoring period (Price et al. 2018). Hutton (2018) found that stream salamander occupancy and abundance declined consistently among all species and age ranges in mining affected streams compared to reference streams, likely due to changes in diet. Larval salamanders experienced a 12-fold decrease in diet autochthony, a 4.2-fold decrease in total prey volume, and a rapid decline in body condition as specific conductivity increased (Hutton 2018). Hutton et al. (In Press) also found salamander occupancy and abundance to be negatively associated with stream conductivity.

Most studies looking at amphibian utilization of mining affected lands have been in stream systems; however a few have documented amphibian use and reproduction in wetlands located on surface mines. Loughman (2005) found that Notophthalmus viridescens was able to breed in natural and artificial wetlands on an abandoned mine in West Virginia, while Ambystoma maculatum was able to reproduce (lay eggs) but no growth or development occurred. Lithobates sylvaticus, although a breeding population was documented $2 \mathrm{~km}$ from the study site, did not utilize the mine wetlands for 
reproduction, however several other anuran species did (Loughman 2005). Loughman (2005) suggested that with proper wetland planning and creation, minelands could be converted to important breeding habitat for amphibians. Lannoo et al. (2009) suggested that mine spoil habitats, including the various wetlands found on them, could be critical habitat to threatened and endangered species. Similarly, Stiles (2017) documented the colonization of 14 amphibian species to a reclaimed strip mine and suggested that reclaimed, restored, and properly managed post-disturbance landscapes may provide adequate amphibian breeding habitat.

A large-scale restoration project was initiated on reclaimed mined land in 2009 within the Monongahela National Forest (MNF), West Virginia to bring back the red spruce (Picea rubens) ecosystem that once occupied high elevation areas in the state. Prior to disturbance from logging in the early 1900s and surface mining in the 1980s and 1990s, the red spruce forest covered over 200,000 ha in WV, but less than 20,000 ha remain today. On the MNF site, a holistic suite of restoration activities have been implemented including soil decompaction, wetland creation, woody debris loading, and planting of native trees and shrubs. To date, over 350,000 trees and shrubs have been planted on over 300 ha and over 1,200 small vernal wetlands have been constructed on the mine impacted land. The suitability of these wetlands as habitat for amphibians, however, is not well understood.

It is important to understand how site and landscape level factors may limit amphibian use of created wetland habitats on surface mines. In this study, my objectives were to: 1) characterize differences in wetland habitat across age classes, 2) estimate amphibian occupancy in the created wetlands, 3) investigate estimated abundance of four 
common amphibian species (Lithobates sylvaticus, Lithobates clamitans, Notophthalmus viridescens, and Ambystoma maculatum), and 4) identify wetland characteristics most important for amphibian utilization of wetlands. Over 1.1 million ha of forest have been disturbed by surface mining in central Appalachia (Bernhardt and Palmer 2011). By understanding which factors are important to amphibian utilization of created wetlands on high elevation surface mines, there is the possibility for successful reforestation and wetland creation on other Appalachian surface mines.

\section{STUDY SITE}

The 16,187.43 ha Mower Tract is located on Cheat Mountain in the Monongahela National Forest, Randolph and Pocahontas Counties, West Virginia. With an elevation of 4,000 ft, the area was historically characterized by red spruce birch forests, poor soils, a thick layer of peat, and scattered wetlands (Byers et al. 2010). Red spruce forests and their associated systems are of high state and global conservation importance and have declined throughout their range in North America (Byers et al. 2010, Walter et al. 2017). The area was logged in the early 1900s and subsequently burned in unnaturally hot wildfires that destroyed the peat and seedstock within it. In the 1980s approximately 809 ha were surface mined for coal. The mined areas were reclaimed by restoring the area to its original contour, compacting the soil, and planting non-native grasses and conifers. Native species were unable to colonize the area due to soil compaction and the pervasiveness of non-native vegetation. The compacted soils also led to slow tree growth and almost nonexistent reproduction. Following reclamation, the land was purchased 
from the Mower Land Company by the U.S. Forest Service as part of the Monongahela National Forest Greenbrier District.

Native reforestation on the Mower Tract began in 2010 with a partnership between the U.S. Forest Service Monongahela National Forest, the U.S. Office of Surface Mining Reclamation and Enforcement's Appalachian Regional Reforestation Initiative, and Green Forests Work, a reforestation oriented 501c3 nonprofit. In order to address the compaction issues, the area was deep ripped using a bulldozer and a ripping shank in the autumn of each year. Wetland creation was done at the time of ripping. Downed trees were left in the ripped area to provide organic material and habitat. The first wetlands, created in 2010, were designed by Thomas Biebighauser, a wildlife and wetlands biologist, and retained some of the non-native conifer cover. Some wetlands created in 2010 were placed just outside of the ripped area in the adjacent woods. Wetlands created in 2012, 2014, and 2016 were created opportunistically where clay or wet soils were identified. Logs, downed trees, and larger rocks were pushed into the wetlands to create wildlife habitat. There were 135 wetlands created in 2010, 75 in 2012, 279 in 2014, and 318 in 2016. Native red spruce and northern hardwoods were planted in the rip trails and wetland vegetation seeded around wetland edges in the spring following creation. Not all of these wetlands hold water for all or part of the year. Reforestation and wetland creation efforts on the Mower Tract are ongoing. 


\section{MATERIALS AND METHODS}

Prior to sampling I identified 40 wetlands, 10 wetlands from each age class (created 2, 4, 6 or 8 years prior to sampling). To determine which factors varied among wetland age classes and were important for amphibian occupancy and abundance, site level and environmental variables were collected at each wetland. At each wetland, a 50 $\mathrm{mL}$ water sample was taken and placed on ice until it could later be processed in the lab for turbidity (FTU), conductivity $\left(\mu \mathrm{S} \mathrm{cm}^{-1}\right)$, total organic carbon $\left(\mathrm{mg} \mathrm{L}^{-1}\right)$, phosphate (PO4 mg L $\left.{ }^{-1}\right), \mathrm{pH}(\mathrm{H}+)$, alkalinity $\left(\mathrm{HCO} 3 \mathrm{mg} \mathrm{L}^{-1}\right)$, chloride $\left(\mathrm{Cl} \mathrm{mg} \mathrm{L}{ }^{-1}\right)$, Sulfate (SO4 mg $\left.\mathrm{L}^{-1}\right)$, nitrate (NO3 $\left.\mathrm{mg} \mathrm{L}^{-1}\right)$, ammonium $\left(\mathrm{NH} 4 \mathrm{mg} \mathrm{L}^{-1}\right)$, calcium $\left(\mathrm{Ca} \mathrm{mg} \mathrm{L}^{-1}\right)$, magnesium $\left(\mathrm{Mg} \mathrm{mg} \mathrm{L}^{-1}\right)$, potassium $\left(\mathrm{K} \mathrm{mg} \mathrm{L}^{-1}\right)$, sodium (NA mg L $\left.{ }^{-1}\right)$, manganese $\left(\mathrm{Mn} \mathrm{mg} \mathrm{L}^{-1}\right)$, and iron $\left(\mathrm{Fe} \mathrm{mg} \mathrm{L} \mathrm{L}^{-1}\right)$. Samples were collected at the field sites and transported in a cooler to the UK Department of Forestry Hydrology Lab for analysis. Water $\mathrm{pH}$ was measured with an Orion Benchtop pH meter (Thermo Fisher Scientific, www.fishersci.com/us/en/home.html). Alkalinity was measured by titration. EC was measured using a YSI conductivity bridge (YSI, Yellow Springs, OH). Total Fe, Mn, Ca, $\mathrm{K}, \mathrm{Mg}$, and Na were measured using a GBC SDS 270 Atomic Adsorption Spectrophotometer (GBC Scientific Equipment, Melbourne, Australia). Ammonium and nitrate were analyzed with a Brun Luebbe (Brun+Luebbe Company, Norderstedt, Germany) auto analyzer. Sulfate, phosphate and chloride was measured using ion chromatography on a Dionex Ion Chromatograph 2000 (Dionex Corp., CA). A Shimadzu TOC-Vcsn analyzer (Shimadzu, Kyoto, Japan) was utilized for measuring TOC concentration. Turbidity was measured with a Hach turbidimeter (Hach, Loveland, CO). 
All sampling, preservation, and analytic protocols followed those outlined in Greenberg et al. (1992). The number of rocks with a diameter $\geq 15 \mathrm{~cm}$ and $\operatorname{logs}$ with a diameter $\geq 4$ $\mathrm{cm}$ were counted. To determine wetland hydroperiod, Solinst Troll pressure transducers (Solinst Levelogger Edge Model 3001) were set at 6 wetlands in each age class (May through October) to measure water level $(\mathrm{cm})$. Loggers were placed in the deepest spot of each wetland and measured water level every 6 hours. Two Solinst Barologgers (Solinst Barologger Edge Model 3001) were placed at opposite ends of the Mower Tract. These recorded barometric pressure $(\mathrm{kPa})$ every 6 hours, so that Levelogger readings could be compensated for atmospheric barometric pressure. Logger data was downloaded and water depth was measured manually using a meter stick at all wetlands at the deepest spot at the time of sampling. Loggers were removed from the field in October 2018. After the loggers were collected from the field Solinst's Levelogger 4.0.3 software C was used to compensate Levelogger reading with barometric pressure from the Barologgers. During the month of July when vegetation growth was at its peak, percent wetland vegetation and canopy cover were measured. Percent wetland vegetation cover (combined emergent and submergent) was visually assessed using a PVC square meter quadrat. The percent vegetation cover was estimated from quadrats placed on the north and south edges of the wetland and in two quadrats from the middle of the wetlands. Overall percent vegetation was calculated by averaging the four percentages from the quadrats. Canopy cover was measured using a spherical crown densiometer from the center of the wetland (Forestry Suppliers, Jackson, MS, USA). GPS Coordinates were taken at all study wetlands and wetlands close to study wetlands. National Land Cover Database (NLCD) $20113 \mathrm{~m}$ resolution land cover data was used to delineate land cover (forest, grassland) (US 
Geological Survey) and a stream shapefile supplied by the US Forest Service Monongahela National Forest was used to determine stream location. Distance to nearest stream, wetland, and forest were measured using the Near tool in the ArcToolBox of ArcMap $^{\mathrm{TM}}$ 10.5.1 within ESRI's ArcGIS® (ESRI 2013).

Amphibian count surveys were conducted five times at each wetland between May and July 2018. Wetlands were sampled using 40 by 23 -cm D-frame dipnets (Ed Cumings, Inc.). The number of net sweeps was determined based on wetland size, with one sweep per every two $\mathrm{m}^{2}$ surface area with 5 - 52 sweeps per wetland (14 \pm 1.7$)$. Each dipnet sweep consisted of placing the dipnet on the bottom of the wetland and dragging it approximately $1 \mathrm{~m}$. Adult and larval amphibians were counted and identified. In a few instances, species identification was confirmed in the lab using a microscope to inspect tooth row morphology. All cover types were sampled evenly (emergent vegetation, log piles, open water, etc.). Wetland surface area $\left(\mathrm{m}^{2}\right)$ was determined prior to sampling.

I used an analysis of variance (ANOVA) to look for differences among age classes in all site covariates collected or calculated on a single occasion, including: wetland size (surface area $\mathrm{m}^{2}$ ), change in wetland water depth $(\mathrm{cm})$, the number of logs, the number of rocks, percent canopy cover, percent vegetation cover in wetland, and distance to nearest stream, wetland, and forest. An additional ANOVA was conducted using water quality data from the second sample. This sample was used because it was the most complete sample (no dry wetlands). One wetland in the 2010 age class was excluded from this analysis because it remained dry throughout the study period. Significant differences for ANOVA's were further analyzed using Tukey's pairwise 
comparison (Tukey, 1949). All ANOVA's were conducted using SPSS 24 (IBM SPSS Statistics).

I used single season single species occupancy models to assess occupancy of Ambystoma maculatum, Notophthalmus viridescens, Lithobates clamitans, Lithobates sylvaticus, and Pseudacris crucifer in R package unmarked (MacKenzie et al. 2002, Fiske and Chandler 2011). This model fits the standard occupancy based on zero inflated binomial mixture models. I checked for correlation among site covariates and did not include any covariates with correlations > 0.7 (Zuur et al. 2009). All continuous covariates were standardized (Schielzeth 2010). I included day of year and day of year ${ }^{2}$ for detection covariates and wetland age, percent canopy cover, percent vegetation cover, mean conductivity, and mean conductivity ${ }^{2}$ for occupancy/abundance covariates. I calculated goodness-of-fit using these models. All occupancy models passed the goodness of fit tests for a Poisson distribution $\left(\chi^{2} p>0.05\right)$. I compared all combinations of day of year, day of year ${ }^{2}$, and the null to determine the model with the lowest Akaike's information criterion corrected for small sample sizes (AICc; Hurvich and Tsai, 1989). For all initial detection models wetland age, mean conductivity, and mean conductivity ${ }^{2}$ were included as site level covariates. I chose the best detection models and ran 10 models with combinations of age, mean conductivity, mean conductivity ${ }^{2}$, percent canopy cover, percent vegetation cover, and a null model. Quadratic terms were only included in models that also contained the lower order term. I used the likelihood of a model given the data $(\exp [-0.5 \cdot \Delta \mathrm{AICc}])$ with a cutoff of $\geq 0.125$ to select supported models (Burnham and Anderson, 2002). 
Abundance of Am. maculatum, N. viridescens, L. clamitans, and L. sylvaticus was assessed using single season single species $\mathrm{N}$ mixture models that fits spatially recurrent count data (Royle 2004, Fiske and Chandler 2011). I checked for correlation among site covariates and did not include any covariates with correlations $>0.7$ (Zuur et al. 2009). All continuous covariates were standardized (Schielzeth 2010). I included day of year and day of year ${ }^{2}$ for detection covariates and wetland age, percent canopy cover, percent vegetation cover, mean conductivity, and mean conductivity ${ }^{2}$ for occupancy/abundance covariates. I calculated goodness-of-fit using these models. The lowest c-hat was used for predictions if c-hat values were between 1-3 for abundance models that did not fit a Poisson distribution $\left(\chi^{2} \mathrm{p}<0.05\right)$. If $\mathrm{c}$-hat values were $>4$, a zero inflated Poisson distribution or non-binomial distribution were fit and the lowest c-hat value was used for all models (Mazerolle 2016). I compared all combinations of day of year, day of year², and the null to determine the model with the lowest Akaike's information criterion corrected for small sample sizes (AICc; Hurvich and Tsai, 1989). For all initial detection models, wetland age, mean conductivity, and mean conductivity ${ }^{2}$ were included as site level covariates. I chose the best detection models and ran 10 models with combinations of age, mean conductivity, mean conductivity ${ }^{2}$, percent canopy cover, percent vegetation cover, and a null model. Quadratic terms were only included in models that also contained the lower order term. I used the likelihood of a model given the data (exp[-0.5 $\triangle \mathrm{AICc}]$ ) with a cutoff of $\geq 0.125$ to select supported models (Burnham and Anderson, 2002).

The detection covariates included day of year and day of year ${ }^{2}$ due to the differences in breeding season timing and duration for each species. For example, the 
early spring pond-breeding amphibians, such as L. sylvaticus, are more likely to peak in abundance in the middle of the study period (late spring and early summer) versus larvae from amphibians that breed later in the season, such as $H$. versicolor. Additionally, some larvae, such as L. clamitans, can remain in the breeding wetlands for multiple years, further influencing the number of individuals that can be found at different times of year, likely being highest when new larvae have hatched and older larvae have not yet metamorphosed. In my study, I noticed metamorphosis of L. clamitans around the middle and end of the study period (late June to July). Wetland age has been demonstrated to influence amphibian use of wetlands due to the number of years that amphibians have been colonizing and returning to the wetlands to breed (Birx-Raybuck et al. 2010, Laan and Verboom 1990). Previous studies on surface mines, primarily in stream salamanders, have identified reduced amphibian occupancy and abundance rates in streams with high conductivity (Hutton et al. In Press, Muncy et al. 2014, Price et al. 2016). Consequently, it is important to determine if conductivity levels are of concern in the created wetland for any of the species.

\section{RESULTS}

I found several differences in habitat parameters among wetland age classes. During the sampling period (May - July) none of the wetlands with leveloggers dried and two without loggers dried, both in the 2 year-old age class. One wetland in the 8 year-old wetland age class was dry for the entire study period. Wetland sizes ranged from 4.5$37.7 \mathrm{~m}^{2}$ in the 2 year-old wetlands, $11.2-89.4 \mathrm{~m}^{2}$ in 4 year-old wetlands, $10.5-66.9 \mathrm{~m}^{2}$ in 6 
year-old wetlands, and $12.0-121.0 \mathrm{~m}^{2}$ in the 8 year-old wetlands. Percent canopy cover ranged from $0-13 \%$ in the 6 year-old wetlands, and $0-99 \%$ in the 8 year-old wetlands. There was no canopy cover in the 2 year-old and 4 year-old wetlands (Table 1). Percent vegetation cover (submergent and emergent combined) averaged $20 \pm 0.06 \%$ (range 7$73 \%$ ) in the 2 year-old wetlands, $44 \pm 0.07 \%$ (range 16-73\%) in the 4 year-old wetlands, $19 \pm 0.04 \%$ (range $2-41 \%$ ) in the 6 year-old wetlands, and $30 \pm 0.08 \%$ (range $3-74 \%$ ) in the 2 year-old wetlands. Mean wetland size, percent canopy cover, percent vegetation cover, distance to the nearest stream, and distance to the nearest forest varied significantly among wetland age classes $(\mathrm{p}<0.05)$. Mean wetland change in water level depth, number of logs, number of rocks, and distance to the nearest wetland did not vary significantly among wetland age classes $(\mathrm{p}<0.05)$. Mean wetland size and canopy cover were greater in 8 year-old wetlands compared to the other age classes $(\mathrm{p}<0.05)$. Percent wetland vegetation cover was significantly greater in 8 year-old and 4 year-old wetlands, distance to the nearest stream was significantly greater in the 2 year-old wetlands, and distance to the nearest forest was significantly greater for the 4 year-old wetlands and lower for the 2 year-old wetlands, as compared to other age classes $(\mathrm{p}<0.05)$ (Table 2). All water quality parameters except chloride $\left(\mathrm{Cl} \mathrm{mg} \mathrm{L}^{-1}\right)$, manganese $\left(\mathrm{Mn} \mathrm{mg} \mathrm{L}^{-1}\right)$, and


nitrate $\left(\mathrm{NO} 3 \mathrm{mg} \mathrm{L}^{-1}\right)$ and ammonia $\left(\mathrm{NO} 4 \mathrm{mg} \mathrm{L}^{-1}\right)$ were significantly greater in the 2 yearold wetlands and sulfate ( $\mathrm{SO} 4 \mathrm{mg} \mathrm{L}^{-1}$ ) was significantly higher and $\mathrm{pH}$ significantly lower in the 8 year-old wetlands than other age classes (Table 3 ).

Over 2,200 amphibian captures were recorded during 5 sampling trips to each of the 40 wetlands from May to July 2018. There were 651 amphibians caught in 8 year-old 
wetlands, 598 in 6 year-old wetlands, 519 in 4 year-old wetlands, and 475 in 2 year-old wetlands. There were 8 species found in 8 year-old wetlands (Am. maculatum, Anaxyrus americanus, Hemidactylium scutatum, Hyla versicolor, L. clamitans, L. sylvaticus, $N$. viridescens, and P. crucifer), 5 in the 4 and 6 year-old wetlands (Am. maculatum, $L$. clamitans, L. sylvaticus, $N$. viridescens and P. crucifer), and 6 in 2 year-old wetlands (Am. maculatum, An. americanus, L. clamitans, L. sylvaticus, $N$. viridescens, and $P$. crucifer).

The supported occupancy models for Am. maculatum included the detection covariates of day of year and day of year ${ }^{2}$, and the occupancy covariates of wetland percent vegetation cover, age, and conductivity (Table 4). At mean conductivity and percent vegetation cover, Am. maculatum predicted occupancy was 0.67 (95\% CI =0.39$0.87)$ in the 2 year-old wetlands, $0.57(95 \% \mathrm{CI}=0.19-0.89)$ in 4 year-old wetlands, 0.69 $(95 \% \mathrm{CI}=0.32-0.92)$ in 6 year-old wetlands, and $0.65(95 \% \mathrm{CI}=0.40-0.84)$ in 8 yearold wetlands. Ambystoma maculatum predicted occupancy was highest at higher conductivity values, reaching a maximum of $0.74(95 \% \mathrm{CI}=0.22-0.98)$ around a conductivity of $74 \mu \mathrm{S} \mathrm{cm}^{-1}$ (Figure 1), and at lower percent wetland vegetation cover, with the highest predicted occupancy of $0.81(95 \% \mathrm{CI}=0.42-0.97)$ at $2 \%$ vegetation cover (Figure 2). Notophthalmus viridescens supported occupancy models included the null for a detection covariate and age and conductivity as occupancy covariates (Table 5). Notophthalmus viridescens estimated occupancy rates at mean conductivity were 0.61 $(95 \% \mathrm{CI}=0.18-0.92)$ in 2 year-old wetlands, $0.84(95 \% \mathrm{CI}=0.34-1.00)$ in 4 year-old wetlands, $0.76(95 \% \mathrm{CI}=0.36-0.95)$ in 6 year-old wetlands, and $0.83(95 \% \mathrm{CI}=0.38$ 0.98) in 8 year-old wetlands and the predicted occupancy increased with conductivity, 
peaking at $0.91(95 \% \mathrm{CI}=0.06-1.00)$ around a conductivity of $74 \mu \mathrm{S} \mathrm{cm}^{-1}$ (Figure 3$)$. Supported models for $L$. clamitans included the null as a detection covariate and age and percent vegetation cover as occupancy covariates (Table 6). At mean percent vegetation cover, predicted occupancy was $0.23(95 \% \mathrm{CI}=0.042-0.66)$ in 2 year-old wetlands, 1.00 $(95 \% \mathrm{CI}=0.00-1)$ in 4 year-old wetlands, $0.56(95 \% \mathrm{CI}=0.188-0.88)$ in 6 year-old wetlands, and $0.26(95 \% \mathrm{CI}=0.0657-0.65)$ in 8 year-old wetlands. Lithobates clamitans predicted occupancy was highest at low vegetation cover, peaking at $1.00(95 \% \mathrm{CI}=$ 0.00-0.00) at 2\% vegetation cover (Figure 4). The null model was the best fit for $L$. sylcaticus with a predicted occupancy of $0.26(95 \% \mathrm{CI}=0.15-0.43)$ (Table 7). Supported occupancy models for $P$. crucifer included day of year and day of year ${ }^{2}$ as detection covariates and conductivity and conductivity ${ }^{2}$ as occupancy covariates (Table 8). Pseudacris crucifer occupancy was highest at intermediate conductivities, with a maximum of 0.59 (95\% CI 0.28-0.84) at approximately $43 \mu \mathrm{S} \mathrm{cm}^{-1}$ (Figure 5).

The supported model for Am. maculatum abundance included day of year and day of year ${ }^{2}$ as detection covariates and age, conductivity and conductivity ${ }^{2}$ as abundance covariates. This species fit the assumptions for a poisson distribution (Table 9). At mean conductivity , Am. maculatum estimated abundance was $4.13 \pm 1.05 \mathrm{SE}(95 \% \mathrm{CI}=2.50$ $6.81)$ in 2 year-old wetlands, $1.52 \pm 0.67(95 \% \mathrm{CI}=0.64-3.61)$ in 4 year-old wetlands, $5.33 \pm 1.96(95 \% \mathrm{CI}=2.60-10.96)$ in 6 year-old wetlands, and $75.28 \pm 21.74(95 \% \mathrm{CI}=$ 42.75-132.58) in 8 year-old wetlands. Abundance was highest at intermediate conductivities, reaching a maximum of $119.46 \pm 44.46(95 \% \mathrm{CI}=57.60-247.76)$ at a conductivity of $46 \mu \mathrm{S} \mathrm{cm}^{-1}$ (Figure 5). The supported model for N. viridescens included day of year and day of year ${ }^{2}$ as detection covariates and age and percent canopy cover as 
abundance covariates (Table 10). A zero inflated Poisson distribution was the best fit for this species. Notophthalmus viridescens abundance was $0.91 \pm 0.39(95 \% \mathrm{CI}=0.39-2.12)$ in 2 year-old wetlands, $2.59 \pm 0.62(95 \% \mathrm{CI}=1.62-4.13)$ in 4 year-old wetlands, $1.73 \pm$ $0.50(95 \%$ 0.98-3.05) in 6 year-old wetlands, and $23.43 \pm 4.33(95 \% \mathrm{CI}=16.32-33.65)$ in 8 year-old wetlands at mean canopy cover. Notophthalmus viridescens abundance was higher at lower canopy cover, with an abundance estimate of $30.57 \pm 6.18(95 \% \mathrm{CI}=$ 20.57-45.44) at $0 \%$ canopy cover (Figure 7). For L. clamitans the best fit model included day of year and day of year ${ }^{2}$ as detection covariates and the null for an abundance covariate (Table 11). This species fit a non-binomial distribution. Estimated abundance was $19.48 \pm 5.96(95 \% \mathrm{CI}=10.69-35.50)$. The best fit models for $L$. sylvaticus included day of year and day of year ${ }^{2}$ for detection covariates and conductivity and the null for abundance covariates (Table 12). Abundance estimates for this species were highest $(61.98 \pm 175.2495 \% \mathrm{CI}=0.56-1638.62)$ at a conductivity of approximately $74 \mu \mathrm{S} \mathrm{cm}^{-1}$ (Figure 8). This species also fit a non-binomial distribution.

\section{DISCUSSION}

I found significant differences in habitat and water quality parameters among age classes. The oldest wetlands tended to be larger in surface area, have higher percent canopy and vegetation cover, shortest distance to nearest forest, higher sulfate, and lower $\mathrm{pH}$, alkalinity, nitrate and ammonia. The youngest wetlands had the highest turbidity, nitrate, and ammonia. Conductivity varied significantly among age classes but all values were relatively low compared to those seen in streams affected by surface mining in 
Kentucky (Hutton et al. In Press, Hutton 2018, Muncy et al. 2014, Price et al. 2016) and comparable to those seen in other wetlands in Wisconsin (Kutka and Bachmann 1990). Amphibian occupancy and abundance tended to be highest at the wetlands with higher or intermediate conductivities and negatively associated with percent vegetation and canopy cover. Age was also important for amphibian occupancy and abundance, although the relationship was not always linear. Abundance for the two salamander species was highest in the 8 year-old wetlands.

I found significant differences in both habitat and water quality parameters among age classes. None of the wetlands with loggers dried during this study. Two wetlands within the 2 year-old age class dried and one wetland within the 8 year-old age class was dry for the entire study period. I had expected to see more ephemeral behavior from wetlands based on anecdotal evidence from US Forest Service observations. The lack of drying was likely due to the above mean precipitation received in the area during the study period (Figure 9) and that wetland water supply was primarily precipitation fed.

Much of the differences seen in the 8 year-old wetlands is likely due to the difference in wetland creation methodology as compared to the younger wetlands. The 8 year-old wetlands were placed outside of the ripped area in the adjacent forest with conifer tree cover retained. This resulted in higher percent canopy cover values in 8 year wetlands than wetlands created in ripped areas that lacked canopy cover around them. The placement of some wetlands in the 8 year-old age class within the forest rather than in the ripped areas also resulted in little to no distance to the nearest forest $(6.24 \pm 4.05 \mathrm{~m})$ compared to wetlands in other age classes (Age 2=68.70 $\pm 9.2 \mathrm{~m}$, Age $4=114.76 \pm 13.14 \mathrm{~m}$, Age $6=63.06 \pm 5.39 \mathrm{~m})$. This proximity to the forest and subsequent retained vegetation 
resulted in highest percent canopy cover and high percent vegetation cover in the 8 yearold wetlands.

The higher percent canopy cover in the 8 year-old wetlands could have contributed to the low $\mathrm{pH}$ values $(<4.0)$ measured in the 8 year-old wetlands due to conifer needle and other organic material deposition, decomposition, and plant respiration (Deano and Robinson 1985, Hughes 2018). Additionally, the Mower Tract wetlands are primarily precipitation fed and high elevation red spruce forests are known to be impacted by acid rain deposition (Adams and Eagar 1992, Driscoll et al. 2001). The pH values found in the wetlands were lower (Age 2=4.89 \pm 0.08 , Age 4=4.77 \pm 0.17 , Age $6=4.82 \pm 0.13$, Age $8=3.20 \pm 0.20$ ) than those found in created vernal pools in other areas, 5.1-5.9 in Wisconsin (Kutka and Bachmann 1990) and 4.55-6.37 in central Ontario (Clark et al. 1986). Acid deposition has been well documented on the MNF (Adams 1999, Adams et al. 1997, Adams et al. 2000, Mathias and Thomas 2018) and the U.S. Forest Service is actively liming large sections of the forest to mitigate the acidity. The lower $\mathrm{pH}$ values in the older wetlands are likely reflective of acid deposition inputs. Soil ripping and digging in the newer wetlands, however, likely exposed unweathered spoil that is capable of buffering acid inputs (Sena et al., 2014 and 2018). Over time, with continued acid inputs, the buffering capacity of the unweathered material will diminish (Sena et al. 2018) and the newer wetlands could become more acidic.

As with $\mathrm{pH}$, the higher sulfate levels in the oldest wetlands are potentially a result of accumulation and breakdown of organic matter and time since soil was disturbed for wetland creation (Hughes 2018). Years of sulfate deposition have accumulated in the forest soils on the MNF and leaching into water resources has been documented (Adams 
et al. 1997; Ryan et al. 1989; Byers et al. 2007). SMCRA allows for the use of topsoil substitutes in steep mountainous areas where soil thickness is limited and soil productivity is low (Surface Mining Control and Reclamation Act 1977). This practice was utilized at Mower and the ripped area was primarily comprised of shale and sandstone rock. The compacted nature of the reclaimed area prior to ripping promoted surface runoff of precipitation and exhibited poor infiltration. As such, much of the buried spoil had not been exposed to atmospheric deposition inputs until the ripping was performed and the sulfate loading observed in forest soils on the MNF had not occurred to a similar extent. Even though sulfate levels in the 8 year-old wetland were more than double the mean of the younger wetlands, sulfate values were far below the reported levels $\left(206.37 \pm 40.33-853.61 \pm 256.42 \mathrm{mg} \mathrm{L}^{-1}\right)$ found in Appalachian streams affected by surface mining (Hutton 2018, Muncy et al. 2014, Price et al. 2016).

The youngest wetlands in the 2 year-old and 4 year-old age classes had the highest turbidity, nitrate, and ammonia values. Likewise, the older wetlands in the 6 yearold and 8 year-old age classes had low turbidity, nitrate, and ammonia values. One of the intended functions of the wetlands is to trap sediment and other suspended material carried by runoff from the ripped areas as the vegetation community establishes. The higher turbidity values in the youngest wetlands is expected due to the recent wetland creation and immature vegetation community in comparison to the older wetland age classes (White 1998). The higher nitrate and ammonia values in the youngest wetlands was likely due to lack of an established microbial and vegetation community to nitrify and denitrify excess ammonia and nitrate and vegetation community to assimilate excess nitrogen in the water (Hargreaves 1998, Reddy et al. 1989). 
Although conductivity did vary significantly among wetland age classes, all values were comparable to the ranges described by Kutka and Bachmann (1990) which ranged from 11.1-49.8 $\mu \mathrm{S} \mathrm{cm}^{-1}$. and averaged $39.9 \pm 2.2 \mu \mathrm{S} \mathrm{cm}^{-1}$ and $9.5-84.1 \mu \mathrm{S} \mathrm{cm}^{-1}$ and averaged $37.9 \pm 2.9 \mu \mathrm{S} \mathrm{cm}^{-1}$ in Wisconsin vernal pools. All values were lower than values seen in streams impacted by surface mines (Hutton et al. In Press, Hutton 2018, Muncy et al. 2014, Price et al. 2016). The highest conductivity $\left(374 \mu \mathrm{S} \mathrm{cm}^{-1}\right)$ was six times lower than the highest conductivity $\left(2365 \pm 72 \mu \mathrm{S} \mathrm{cm}^{-1}\right)$ reported by Price et al. (2016) in streams affected by surface mining and was at least two times smaller than the lowest reported conductivity by Hutton et al. (2018) in sites impacted by mining $\left(737 \mu \mathrm{S} \mathrm{cm}^{-1}\right)$. Although previous studies have demonstrated high conductivity in streams associated with mining, my mean wetland conductivity was far below the U.S. EPA's conductivity benchmark of $300 \mu \mathrm{S} \mathrm{cm}^{-1}$ for aquatic life in central Appalachia (US EPA 2011) with only one wetland exceeding the benchmark on one occasion $\left(374 \mu \mathrm{S} \mathrm{cm}^{-1}\right)$.

I captured all but one species that I expected to find, including Am. maculatum, An. americanus, Hemidactylium scutatum, Hyla versicolor, L. clamitans, L. sylvaticus, $N$. viridescens, and P. crucifer. Although Scaphiopus holbrookii likely occurs within the area, they were likely not seen due to their irregular breeding patterns (Lannoo 2005).

The best supported models for amphibian occupancy and abundance included wetland mean conductivity, mean conductivity ${ }^{2}$, age, percent vegetation cover, and percent canopy cover as occupancy and abundance covariates. I found that amphibian occupancy and abundance tended to be highest at higher or intermediate conductivity values and lower percent vegetation and canopy cover. Abundance of Am. maculatum and $N$. viridescens was highest in the oldest (8 year-old) wetlands. 
Because amphibians osmoregulate through their skin, they are sensitive to changes in ion (conductivity) levels within their habitats (Ultsch et al. 1999). Karraker et al. (2008) found that embryonic and larval survival were reduced when exposed to moderate $\left(500 \mu \mathrm{S} \mathrm{cm}^{-1}\right)$ and high $\left(800 \mu \mathrm{S} \mathrm{cm}^{-1}\right)$ for Am. Maculatum and high conductivities in L. sylvaticus in experimental mesocosms. Chambers (2011) found there to be a significant positive effect of increasing conductivity exposure on baseline amphibian corticosterone levels in Am. jeffersonianum after 1 week of exposure, but not in L. sylvaticus or H. versicolor. Ambystoma jeffersonianum prey consumption was negatively associated with increasing conductivity (Chambers 2011). Sanzo and Hecnar (2005) found that amphibian survivorship, time to metamorphosis, weight and activity decreased and physical abnormalities increased as salt (ion) concentration $\left(0-1030 \mathrm{mg} \mathrm{L}^{-}\right.$ ${ }^{1}$ ) increased in a 90 day chronic exposure. Additionally, in mesocosms with retention pond sediments with elevated metal levels and chloride concentrations $100 \%$ of $L$. sylvaticus embryos died (Snodgrass et al. 2008); however, An. americanus only experienced reduced size at metamorphosis due to exposure, indicating differences in species response to ion exposure (Snodgrass et al. 2008). Because conductivity values found in this study were lower than those referenced in stream studies where reduced occupancy and abundance rates were reported (Hutton 2018, Muncy et al. 2014, Price et al. 2016), were similar to those found in other wetlands (Kutka and Bachmann 1990), and had mean conductivity for all age classes below the U.S. EPA's conductivity benchmark of $300 \mu \mathrm{S} \mathrm{cm}^{-1}$ for aquatic life in central Appalachia (US EPA 2011), it is unlikely that conductivity is limiting to amphibian utilization of the created wetlands. 
Older wetlands have had a longer period of time for amphibians to colonize them compared to younger wetlands, therefore wetland age has the potential to influence amphibian utilization of created wetlands (Birx-Raybuck 2010, Laan and Verboom 1990, Lehtinen and Galatowitsch 2001). Laan and Verboom (1990) found the wetland age was the best predictor of the number of species in new pools and a strong relationship between species abundance and colonization rates. They hypothesized that was likely due to the amount of time that the pools have been exposed to colonization, with the older pools allowing more time for amphibian colonization and therefore exhibiting higher abundances (Laan and Verboom 1990). Birx-Raybuck et al. (2010) found that the presence of four anuran species was associated with the age of retention ponds. Spring Peepers (P. crucifer) and Bullfrogs (L. catesbeianus) were found more in the older ponds, versus the Cope's Gray Treefrog (H. chrysoscelis) and Fowler's Toad (An. fowleri), which were found more in the newer wetlands (Birx-Raybuck et al. 2010). However, multiple studies have shown that amphibian species can colonize new wetlands sometimes even within a few months since creation, indicating that species dispersal capabilities and habitat connectivity are also likely influential (Lehtinen and Galatowitsch 2001, Vasconcelos and Calhoun 2006). My results support the idea that wetlands can be colonized quickly, with the youngest wetlands having the second highest number of species captured (6 species); however, it should be noted that abundances of two salamander species, Am. macularum and $N$. viridescens, were highest in the oldest wetlands, supporting the conclusions of Laan and Verboom (1990) that older wetlands have higher abundances due to the time allowed for colonization. 
Many amphibians, including salamanders and hylids, have demonstrated a positive relationship with aquatic vegetation cover (Shulse et al. 2010). Wassens et al. (2010) found that the occupancy of waterbodies by Growling Grass Frog (Litoria raniformis) was strongly linked to vegetation complexity and that vegetation complexity may reduce the impacts of higher predator densities (Wassens et al. 2010); however, in contradiction to those findings, my observations indicated occupancy rates decreasing with increasing percent vegetation cover, perhaps resulting from inadequate amphibian sampling protocol in aquatic vegetation.

My results support the conclusions that pond breeding amphibian utilization is negatively associated with canopy cover (Skelly et al. 2002, Skelly et al. 2005, Skelly et al. 2014). Skelly et al. (2002) found that canopy development was associated with Spring Peeper (P. crucifer) extinction and persistence of Wood Frog (L. sylvaticus) populations. Both species grew more slowly in closed versus open canopy wetlands (Skelly et al. 2002). Skelly et al. (2005) found that amphibian richness was highest in wetlands that received more light and field transplants showed that development of canopy cover generalists was less affected by wetland light compared to canopy cover specialists. In an experiment where trees were felled around wetlands to create more open canopy, manipulated wetlands maintained more amphibian species during five years postmanipulation versus those that were not manipulated (Skelly et al. 2014). The effects of canopy cover may also be associated with the proximity to the nearest forest, as the wetlands with significantly high canopy cover were those placed outside of the ripped area in the adjacent forest. There is a positive relationship between habitat connectivity and amphibian occupancy and colonization of wetlands (Hamer et al. 2016). Laan and 
Verboom (1990) found that distance to nearest woodland and age were important predictors of amphibian utilization of created wetlands. Birx-Raybuck et al. (2010) found that occupancy of amphibians decreased with increasing distance to riparian area and that occupancy varied with wetland age. Therefore, it may be easier for amphibians to colonize and utilize the 8 year-old wetlands due to their proximity to forest habitat.

Abundance for Am. maculatum and $N$. viridescens was highest in the oldest wetlands, potentially due to their larger size. Millikin et al. (2019) found lower waterborne corticosterone levels, and therefore lower stress levels, in larval Am. maculatum in wetlands with a larger diameter from the same study site (Mower Tract, Monongahela National Forest). Other possible explanations include wetland age, as the older wetlands have had a longer period of time for amphibians to colonize them, and the little to no distance to the nearest forest, potentially allowing for easier colonization than younger wetlands placed within the ripped areas (Laan and Verboom 1990).

My results indicate that created wetlands on reforested surface mines could be adequate habitat for pond breeding amphibians. Despite low mean $\mathrm{pH}$ in the 8 year-old wetlands, there was a high number of amphibian captures (651 in 8 year-old wetlands) and the oldest wetlands maintained the most species caught and highest abundances of Am. maculatum and $N$. viridescens. The youngest wetlands, which were 2 years-old at the time of creation, had the second highest number of species caught and 475 total amphibians captures, indicating wetland colonization in a relatively short period of time. Conductivity levels, which previous studies suggest as a major limitation to stream salamander occupancy and abundance in streams affected by mining, were lower than those found in streams affected by mining (Hutton 2018, Muncy et al. 2014, Price et al. 
2016) and were similar or lower than those described in Wisconsin vernal pools (Kutka and Bachmann 1990). Sulfate levels were also lower than those found in other studies, many of which cite high sulfates in mining affected streams with reduced amphibian occupancy and abundance (Hutton 2018, Muncy et al. 2014, Price et al. 2016).

Further research is needed to determine if these wetlands are providing the same functions and are within the normal parameters as reference wetlands within the region. These questions must be addressed and amphibian recruitment studied over time to determine if these wetlands will provide long-term pond breeding amphibian habitat. If evidence supports that created wetlands provide similar function over time, there is abundant opportunity to create wetland habitat on reforested surface mines throughout the Allegheny and Appalachian Mountains, providing habitat not only for pond breeding amphibians and other wildlife, but potentially serving other wetland ecosystem functions that benefit humans, such as flood mitigation. 


\section{TABLES}

\section{Table 1. Wetland Physical Parameter Ranges}

Range of wetland size $\left(\mathrm{m}^{2}\right)$, change in depth $(\mathrm{cm})$, number of $\operatorname{logs}$ (diameter $\geq 15 \mathrm{~cm}$ ), number of rocks (diameter $\geq 4 \mathrm{~cm}$ ), canopy cover $(\%)$, vegetation cover $(\%)$, distance to nearest stream $(\mathrm{m})$, distance to nearest wetland $(\mathrm{m})$, and distance to forest $(\mathrm{m})$ for each wetland age class.

\begin{tabular}{|c|c|c|c|c|}
\hline \multicolumn{2}{|c}{ Age 2 } & Age 4 & Age 6 & Age 8 \\
\hline Wetland Size (m) & $4.51-37.72$ & $11.15-89.37$ & $10.50-66.89$ & $12-121.00$ \\
\hline Change in Depth (cm) & $5.78-17.30$ & $3.58-13.61$ & $0-10.75$ & $7.71-24.26$ \\
\hline Number of Logs & $0-4$ & $0-7$ & $0-4$ & $0-11$ \\
\hline Number of Rocks & $0-9$ & $0-3$ & $0-6$ & $0-12$ \\
\hline Canopy Cover (\%) & $0-0$ & $0-0$ & $0-13.30$ & $0-98.70$ \\
\hline Vegetation Cover (\%) & $7-73$ & $16-73$ & $2-41$ & $3-74$ \\
\hline Distance to Stream (m) & $520.98-$ & $377.75-$ & $495.45-$ & $435.96-$ \\
\hline Distance to Wetland (m) & 1337.06 & 528.42 & 522.56 & 650.93 \\
\hline Distance to Forest (m) & $18.36-14.51$ & $4.20-30.67$ & $5.40-27.41$ & $6.96-337.06$ \\
\hline
\end{tabular}




\section{Table 2. Wetland Physical Parameter ANOVA Results}

Mean $( \pm \mathrm{SE})$ wetland size $\left(\mathrm{m}^{2}\right)$, change in depth $(\mathrm{cm})$, number of $\operatorname{logs}$ (diameter $\left.\geq 15 \mathrm{~cm}\right)$, number of rocks (diameter $\geq 4 \mathrm{~cm})$, canopy cover (\%), vegetation cover $(\%)$, distance to nearest stream $(\mathrm{m})$, distance to nearest wetland $(\mathrm{m})$, and distance to forest $(\mathrm{m})$ for each wetland age class. Significant differences are denoted with an asterisk. Differences among groups are denoted using letters.

$\begin{array}{llll}\text { Age } 2 & \text { Age } 4 & \text { Age 6 } & \text { Age 8 }\end{array}$

\begin{tabular}{|c|c|c|c|c|}
\hline $\begin{array}{c}\text { Wetland Size } \\
\left.\mathbf{( m}^{2}\right)^{*}\end{array}$ & $16.53 \pm 3.12^{\mathrm{a}}$ & $37.92 \pm 7.84^{\mathrm{a}}$ & $34.88 \pm 5.46^{\mathrm{a}}$ & $48.54 \pm 11.38^{\mathrm{b}}$ \\
\hline $\begin{array}{c}\text { Change in } \\
\text { Depth (cm) }\end{array}$ & $11.83 \pm 1.05^{\mathrm{a}}$ & $9.02 \pm 1.05^{\mathrm{a}}$ & $8.73 \pm 0.99^{\mathrm{a}}$ & $11.66 \pm 1.66^{\mathrm{a}}$ \\
\hline $\begin{array}{c}\text { Number of } \\
\text { Logs }\end{array}$ & $1.18 \pm 0.38^{\mathrm{a}}$ & $1.7 \pm 0.83^{\mathrm{a}}$ & $2.10 \pm 0.46^{\mathrm{a}}$ & $2.90 \pm 1.23^{\mathrm{a}}$ \\
\hline $\begin{array}{c}\text { Number of } \\
\text { Rocks }\end{array}$ & $2.18 \pm 0.95^{\mathrm{a}}$ & $0.40 \pm 0.31^{\mathrm{a}}$ & $0.80 \pm 0.61^{\mathrm{a}}$ & $1.90 \pm 1.30^{\mathrm{a}}$ \\
\hline $\begin{array}{c}\text { Canopy Cover } \\
(\boldsymbol{\%})^{*}\end{array}$ & $0 \pm 0^{\mathrm{a}}$ & $0 \pm 0^{\mathrm{a}}$ & $2.37 \pm 1.59^{\mathrm{a}}$ & $49.19 \pm 13.61^{\mathrm{b}}$ \\
\hline $\begin{array}{c}\text { Vegetation } \\
\text { Cover (\%) }\end{array}$ & $2 \pm 0.06^{\mathrm{a}}$ & $44 \pm 0.07^{\mathrm{b}}$ & $19 \pm 0.04^{\mathrm{a}}$ & $30 \pm 0.08^{\mathrm{ab}}$ \\
\hline $\begin{array}{c}\text { Distance to } \\
\text { Stream (m) }\end{array}$ & $1059.13 \pm 71.71^{\mathrm{b}}$ & $463.55 \pm 17.72^{\mathrm{a}}$ & $504.61 \pm 2.80^{\mathrm{a}}$ & $533.29 \pm 22.77^{\mathrm{a}}$ \\
\hline $\begin{array}{c}\text { Distance to } \\
\text { Wetland (m) }\end{array}$ & $8.69 \pm 0.89^{\mathrm{a}}$ & $12.15 \pm 2.34^{\mathrm{a}}$ & $13.64 \pm 1.98^{\mathrm{a}}$ & $56.27 \pm 35.20^{\mathrm{a}}$ \\
\hline $\begin{array}{c}\text { Distance to } \\
\text { Forest (m) }\end{array}$ & $68.70 \pm 9.29^{\mathrm{a}}$ & $114.76 \pm 13.14^{\mathrm{b}}$ & $63.06 \pm 5.39^{\mathrm{a}}$ & $6.24 \pm 4.05^{\mathrm{c}}$ \\
\hline
\end{tabular}




\section{Table 3. Wetland Water Chemistry ANOVA Results}

Mean $( \pm \mathrm{SE})$ turbidity $(\mathrm{FTU})$, conductivity $\left(\mu \mathrm{S} \mathrm{cm}^{-1}\right)$, total organic carbon $(\mathrm{TOC})\left(\mathrm{mg} \mathrm{\textrm {L } ^ { - }}\right.$ $\left.{ }^{1}\right)$, phosphate (PO4) $\left(\mathrm{mg} \mathrm{L}^{-1}\right), \mathrm{pH}(\mathrm{H}+)$, alkalinity $(\mathrm{HCO} 3)\left(\mathrm{mg} \mathrm{L}^{-1}\right)$, chloride $(\mathrm{Cl})\left(\mathrm{mg} \mathrm{L}^{-}\right.$ $\left.{ }^{1}\right)$, sulfate (SO4) $\left(\mathrm{mg} \mathrm{L}^{-1}\right)$, nitrate $(\mathrm{NO} 3)\left(\mathrm{mg} \mathrm{L}^{-1}\right)$, ammonia $(\mathrm{NH} 4)\left(\mathrm{mg} \mathrm{L}^{-1}\right)$, calcium (Ca) $\left(\mathrm{mg} \mathrm{L}^{-1}\right)$, magnesium $(\mathrm{Mg})\left(\mathrm{mg} \mathrm{L}^{-1}\right)$, potassium $(\mathrm{K})\left(\mathrm{mg} \mathrm{L}^{-1}\right)$, sodium $(\mathrm{Na})\left(\mathrm{mg} \mathrm{L}^{-1}\right)$, manganese $(\mathrm{Mn})\left(\mathrm{mg} \mathrm{L}^{-1}\right)$, and iron $(\mathrm{Fe})\left(\mathrm{mg} \mathrm{L}^{-1}\right)$ for each age class. Significant differences are denoted with an asterisk. Differences among groups are denoted using letters.

Age 2

\begin{tabular}{|c|c|c|c|c|}
\hline $\begin{array}{l}\text { Turbidity } \\
\text { (FTU)* }\end{array}$ & $25.51 \pm 3.77^{\mathrm{a}}$ & $10.79 \pm 3.58^{b}$ & $6.12 \pm 4.92^{b}$ & $4.16 \pm 1.88^{b}$ \\
\hline$\underset{\left.\mathrm{cm}^{-1}\right)^{*}}{\text { Conductivity }}(\boldsymbol{\mu S S}$ & $39.68 \pm 2.56^{\mathrm{ab}}$ & $31.27 \pm 2.83^{\mathrm{ac}}$ & $49.47 \pm 5.87^{b}$ & $23.22 \pm 1.48^{\mathrm{c}}$ \\
\hline $\operatorname{TOC}\left(\mathrm{mg} \mathrm{L}^{-1}\right)^{*}$ & $2.35 \pm 0.14^{\mathrm{a}}$ & $2.61 \pm 0.26^{\mathrm{ab}}$ & $3.33 \pm 0.17^{b}$ & $3.26 \pm 0.34^{\mathrm{ab}}$ \\
\hline PO4 $\left(\mathrm{mg} \mathrm{L}^{-1}\right)^{*}$ & $0.46 \pm 0.17^{\mathrm{ac}}$ & $0.19 \pm 0.13^{\mathrm{a}}$ & $1.06 \pm 0.02^{\mathrm{b}}$ & $0.87 \pm 0.18^{b c}$ \\
\hline pH $(\mathbf{H}+)^{*}$ & $4.89 \pm 0.08^{\mathrm{a}}$ & $4.77 \pm 0.17^{\mathrm{a}}$ & $4.82 \pm 0.13^{\mathrm{a}}$ & $3.20 \pm 0.20^{\mathrm{b}}$ \\
\hline $\begin{array}{l}\text { Alkalinity } \\
\left(\mathrm{mg} \mathrm{L}^{-1}\right)^{*}\end{array}$ & $21.12 \pm 3.72^{\mathrm{a}}$ & $14.52 \pm 3.85^{\mathrm{ab}}$ & $29.52 \pm 6.75^{\mathrm{a}}$ & $0.00 \pm 0.00^{\mathrm{b}}$ \\
\hline $\mathrm{Cl}\left(\mathrm{mg} \mathrm{L}^{-1}\right)$ & $0.36 \pm 0.06^{\mathrm{a}}$ & $0.29 \pm 0.05^{\mathrm{a}}$ & $0.46 \pm 0.06^{\mathrm{a}}$ & $0.29 \pm 0.05^{\mathrm{a}}$ \\
\hline SO4 $\left(\mathrm{mg} \mathrm{L}^{-1}\right)^{*}$ & $0.81 \pm 0.22^{\mathrm{a}}$ & $0.89 \pm 0.06^{\mathrm{a}}$ & $0.74 \pm 0.07^{\mathrm{a}}$ & $2.15 \pm 0.43^{\mathrm{b}}$ \\
\hline $\operatorname{NO3}\left(\mathrm{mg} \mathrm{L}^{-1}\right)^{*}$ & $0.12 \pm 0.02^{\mathrm{a}}$ & $0.05 \pm 0.02^{b}$ & $0.01 \pm 0.01^{\mathrm{b}}$ & $0.01 \pm 0.02^{\mathrm{b}}$ \\
\hline NH4 $\left(\mathrm{mg} \mathrm{L}^{-1}\right)^{*}$ & $0.23 \pm 0.05^{\mathrm{a}}$ & $0.10 \pm 0.04^{\mathrm{ab}}$ & $0.01 \pm 0.01^{b}$ & $0.03 \pm 0.02^{\mathrm{b}}$ \\
\hline $\mathrm{Ca}\left(\mathrm{mg} \mathrm{L}^{-1}\right)^{*}$ & $0.51 \pm 0.08^{\mathrm{ab}}$ & $0.50 \pm 0.16^{\mathrm{a}}$ & $0.93 \pm 0.10^{b}$ & $0.33 \pm 0.06^{\mathrm{a}}$ \\
\hline $\operatorname{Mg}\left(\operatorname{mg~L^{-1}}\right)^{*}$ & $1.15 \pm 0.22^{\mathrm{ab}}$ & $0.55 \pm 0.13^{\mathrm{a}}$ & $2.11 \pm 0.41^{b}$ & $0.30 \pm 0.12^{\mathrm{a}}$ \\
\hline $\mathbf{K}\left(\mathrm{mg} \mathrm{L}^{-1}\right)^{*}$ & $1.55 \pm 0.11^{\mathrm{a}}$ & $0.76 \pm 0.09^{\mathrm{bc}}$ & $1.09 \pm 0.12^{\mathrm{ab}}$ & $0.59 \pm 0.08^{c}$ \\
\hline $\mathrm{Na}\left(\mathrm{mg} \mathrm{L}^{-1}\right)^{*}$ & $0.11 \pm 0.01^{\mathrm{a}}$ & $0.12 \pm 0.01^{\mathrm{a}}$ & $0.16 \pm 0.01^{\mathrm{ab}}$ & $0.18 \pm 0.02^{\mathrm{b}}$ \\
\hline $\operatorname{Mn}\left(\mathrm{mg} \mathrm{L}^{-1}\right)$ & $0.06 \pm 0.03^{\mathrm{a}}$ & $0.05 \pm 0.01^{\mathrm{a}}$ & $0.11 \pm 0.03^{\mathrm{a}}$ & $0.10 \pm 0.03^{\mathrm{a}}$ \\
\hline $\mathrm{Fe}\left(\mathrm{mg} \mathrm{L}^{-1}\right)$ & $0.44 \pm 0.05^{\mathrm{a}}$ & $0.30 \pm 0.08^{\mathrm{a}}$ & $0.45 \pm 0.06^{\mathrm{a}}$ & $0.37 \pm 0.07^{a}$ \\
\hline
\end{tabular}


Table 4. Ambystoma maculatum Occupancy Models

Ambystoma maculatum (AMAC) occupancy models ranked from best to worst. Detection covariates are day of year (DOY), and day of year squared $\left(\mathrm{DOY}^{2}\right)$. Occupancy covariates were wetland age, conductivity $\left(\mu \mathrm{S} \mathrm{cm}^{-1}\right)$, conductivity $\left(\mu \mathrm{S} \mathrm{cm}{ }^{-1}\right)$, vegetation cover $(\%)$, and canopy cover $(\%)$.

\begin{tabular}{|c|c|c|c|c|c|c|c|c|c|c|c|}
\hline df & AIC & $\begin{array}{c}\text { Delta } \\
\text { AIC }\end{array}$ & $\begin{array}{c}\text { Model } \\
\text { Likelihood }\end{array}$ & $\begin{array}{c}\text { AIC } \\
\text { Weight }\end{array}$ & DOY & DOY $^{2}$ & Age & Conductivity & Conductivity $^{2}$ & $\begin{array}{c}\text { Vegetation } \\
\text { Cover }\end{array}$ & $\begin{array}{c}\text { Canopy } \\
\text { Cover }\end{array}$ \\
\hline 5 & 175.7 & 0.00 & 1.00 & 0.38 & 1.41 & -1.20 & & & & -0.93 & \\
\hline 5 & 178.1 & 2.42 & 0.30 & 0.11 & 1.40 & -1.19 & & 0.81 & & & \\
\hline 7 & 178.3 & 2.57 & 0.28 & 0.10 & 1.41 & -1.20 & + & & & & \\
\hline 9 & 178.4 & 2.68 & 0.26 & 0.10 & 1.42 & -1.22 & + & 1.62 & -1.22 & & \\
\hline 4 & 178.6 & 2.86 & 0.24 & 0.09 & 1.42 & -1.21 & & & & & \\
\hline 8 & 178.9 & 3.18 & 0.20 & 0.08 & 1.38 & -1.18 & + & 1.69 & & & \\
\hline 6 & 179.7 & 3.98 & 0.14 & 0.05 & 1.41 & -1.20 & & 0.90 & -0.43 & & \\
\hline 5 & 180.5 & 4.86 & 0.09 & 0.03 & 1.42 & -1.21 & & & & & 0.32 \\
\hline 8 & 180.7 & 4.97 & 0.08 & 0.03 & 1.41 & -1.20 & + & & & & 0.46 \\
\hline 8 & 180.9 & 5.25 & 0.07 & 0.03 & 1.41 & -1.20 & + & & & -0.38 & \\
\hline
\end{tabular}


Table 5. Notophthalmus viridescens Occupancy Models

Notophthalmus viridescens (NVIR)occupancy models ranked from best to worst. Detection covariates are day of year (DOY), and day of year squared $\left(\mathrm{DOY}^{2}\right)$. Occupancy covariates were wetland age, conductivity $\left(\mu \mathrm{S} \mathrm{cm}^{-1}\right)$, conductivity $\left(\mu \mathrm{S} \mathrm{cm}{ }^{-1}\right)$, vegetation cover $(\%)$, and canopy cover $(\%)$.

\begin{tabular}{|c|c|c|c|c|c|c|c|c|c|c|c|}
\hline df & AIC & $\begin{array}{c}\text { Delta } \\
\text { AIC }\end{array}$ & $\begin{array}{c}\text { Model } \\
\text { Likelihood }\end{array}$ & $\begin{array}{c}\text { AIC } \\
\text { Weight }\end{array}$ & DOY & DOY $^{2}$ & Age & Conductivity & Conductivity $^{2}$ & $\begin{array}{c}\text { Vegetation } \\
\text { Cover }\end{array}$ & $\begin{array}{c}\text { Canopy } \\
\text { Cover }\end{array}$ \\
\hline 6 & 249.74 & 0.00 & 1.00 & 0.27 & & & + & 1.85 & & & \\
\hline 3 & 250.21 & 0.46 & 0.79 & 0.21 & & & & 0.71 & & & \\
\hline 2 & 250.44 & 0.70 & 0.70 & 0.19 & & & & & & & \\
\hline 7 & 252.07 & 2.33 & 0.31 & 0.08 & & & + & 2.00 & -0.55 & & \\
\hline 3 & 252.48 & 2.74 & 0.25 & 0.07 & & & & & & 0.23 & \\
\hline 4 & 252.62 & 2.88 & 0.24 & 0.06 & & & & 0.70 & 0.08 & & \\
\hline 3 & 252.76 & 3.02 & 0.22 & 0.06 & & & & & & & 0.06 \\
\hline 5 & 253.42 & 3.68 & 0.16 & 0.04 & & & + & & & & \\
\hline 6 & 255.92 & 6.18 & 0.05 & 0.01 & & & + & & & 0.32 & \\
\hline 6 & 256.06 & 6.32 & 0.04 & 0.01 & & & + & & & & 0.21 \\
\hline
\end{tabular}


Table 6. Lithobates clamitans Occupancy Models

Lithobates clamitans (LCLA) occupancy models ranked from best to worst. Detection covariates are day of year (DOY), and day of year squared (DOY2). Occupancy covariates were wetland age, conductivity $\left(\mu \mathrm{S} \mathrm{cm}^{-1}\right)$, conductivity ${ }^{2}\left(\mu \mathrm{S} \mathrm{cm}{ }^{-1}\right)$, vegetation cover $(\%)$, and canopy cover (\%).

\begin{tabular}{|c|c|c|c|c|c|c|c|c|c|c|c|}
\hline df & AIC & $\begin{array}{c}\text { Delta } \\
\text { AIC }\end{array}$ & $\begin{array}{c}\text { Model } \\
\text { Likelihood }\end{array}$ & $\begin{array}{c}\text { AIC } \\
\text { Weight }\end{array}$ & DOY & DOY $^{2}$ & Age & Conductivity & Conductivity $^{2}$ & $\begin{array}{l}\text { Vegetation } \\
\text { Cover }\end{array}$ & $\begin{array}{c}\text { Canopy } \\
\text { Cover }\end{array}$ \\
\hline 6 & 188.48 & 0.00 & 1.00 & 0.64 & & & + & & & -1.72 & \\
\hline 5 & 190.78 & 2.30 & 0.32 & 0.20 & & & + & & & & \\
\hline 6 & 192.87 & 4.39 & 0.11 & 0.07 & & & + & & & & 0.40 \\
\hline 6 & 193.46 & 4.98 & 0.08 & 0.05 & & & + & 0.16 & & & \\
\hline 7 & 195.64 & 7.16 & 0.03 & 0.02 & & & + & 0.48 & -0.33 & & \\
\hline 2 & 199.25 & 10.77 & 0.00 & 0.00 & & & & & & & \\
\hline 3 & 200.66 & 12.18 & 0.00 & 0.00 & & & & & & & -0.31 \\
\hline 3 & 200.87 & 12.39 & 0.00 & 0.00 & & & & 0.29 & & & \\
\hline 3 & 201.50 & 13.02 & 0.00 & 0.00 & & & & & & 0.10 & \\
\hline 4 & 202.50 & 14.02 & 0.00 & 0.00 & & & & 0.40 & -0.23 & & \\
\hline
\end{tabular}


Table 7. Lithobates sylvaticus Occupancy Models

Lithobates sylvaticus (LSYL) occupancy models ranked from best to worst. Detection covariates are day of year (DOY), and day of year squared $\left(\mathrm{DOY}^{2}\right)$. Occupancy covariates were wetland age, conductivity $\left(\mu \mathrm{S} \mathrm{cm}^{-1}\right)$, conductivity ${ }^{2}\left(\mu \mathrm{S} \mathrm{cm}{ }^{-1}\right)$, vegetation cover $(\%)$, and canopy cover (\%).

\begin{tabular}{|c|c|c|c|c|c|c|c|c|c|c|c|}
\hline df & AIC & $\begin{array}{l}\text { Delta } \\
\text { AIC }\end{array}$ & $\begin{array}{c}\text { Model } \\
\text { Likelihood }\end{array}$ & $\begin{array}{c}\text { AIC } \\
\text { Weight }\end{array}$ & DOY & DOY $^{2}$ & Age & Conductivity & Conductivity $^{2}$ & $\begin{array}{c}\text { Vegetation } \\
\text { Cover }\end{array}$ & $\begin{array}{c}\text { Canopy } \\
\text { Cover }\end{array}$ \\
\hline 2 & 117.69 & 0.00 & 1.00 & 0.43 & & & & & & & \\
\hline 4 & 119.78 & 2.10 & 0.35 & 0.15 & & & & 0.30 & -0.75 & & \\
\hline 3 & 120.00 & 2.31 & 0.31 & 0.13 & & & & & & & 0.06 \\
\hline 3 & 120.01 & 2.32 & 0.31 & 0.13 & & & & & & 0.05 & \\
\hline 3 & 120.03 & 2.34 & 0.31 & 0.13 & & & & -0.01 & & & \\
\hline 5 & 124.59 & 6.90 & 0.03 & 0.01 & & & + & & & & \\
\hline 6 & 126.86 & 9.17 & 0.01 & 0.00 & & & + & & & & 0.40 \\
\hline 6 & 127.37 & 9.68 & 0.01 & 0.00 & & & + & -0.03 & & & \\
\hline 6 & 127.37 & 9.68 & 0.01 & 0.00 & & & + & 0.00 & & & \\
\hline 7 & 128.03 & 10.34 & 0.01 & 0.00 & & & + & 0.38 & -0.87 & & \\
\hline
\end{tabular}


Table 8. Pseudacris crucifer Occupancy Models

Pseudacris crucifer (PCRU) occupancy models ranked from best to worst. Detection covariates are day of year (DOY), and day of year squared $\left(\mathrm{DOY}^{2}\right)$. Occupancy covariates were wetland age, conductivity $\left(\mu \mathrm{S} \mathrm{cm}^{-1}\right)$, conductivity $\left(\mu \mathrm{S} \mathrm{cm}{ }^{-1}\right)$, vegetation cover $(\%)$, and canopy cover (\%).

\begin{tabular}{|c|c|c|c|c|c|c|c|c|c|c|c|}
\hline df & AIC & $\begin{array}{l}\text { Delta } \\
\text { AIC }\end{array}$ & $\begin{array}{c}\text { Model } \\
\text { Likelihood }\end{array}$ & $\begin{array}{c}\text { AIC } \\
\text { Weight }\end{array}$ & DOY & DOY $^{2}$ & Age & Conductivity & Conductivity $^{2}$ & $\begin{array}{c}\text { Vegetation } \\
\text { Cover }\end{array}$ & $\begin{array}{c}\text { Canopy } \\
\text { Cover }\end{array}$ \\
\hline 6 & 103.05 & 0.00 & 1.00 & 0.70 & 2.89 & -3.15 & & 1.33 & -1.35 & & \\
\hline 4 & 106.70 & 3.65 & 0.16 & 0.11 & 2.92 & -3.17 & & & & & \\
\hline 5 & 107.24 & 4.20 & 0.12 & 0.09 & 2.91 & -3.17 & & & & & 0.74 \\
\hline 5 & 108.27 & 5.23 & 0.07 & 0.05 & 2.90 & -3.16 & & 0.37 & & & \\
\hline 5 & 109.06 & 6.01 & 0.05 & 0.03 & 2.91 & -3.17 & & & & 0.18 & \\
\hline 9 & 111.73 & 8.69 & 0.01 & 0.01 & 2.88 & -3.14 & + & 1.65 & -1.80 & & \\
\hline 7 & 112.92 & 9.88 & 0.01 & 0.00 & 2.90 & -3.16 & + & & & & \\
\hline 8 & 114.22 & 11.17 & 0.00 & 0.00 & 2.90 & -3.16 & + & & & 0.71 & \\
\hline 8 & 115.08 & 12.03 & 0.00 & 0.00 & 2.91 & -3.16 & + & & & & -0.66 \\
\hline 8 & 115.55 & 12.51 & 0.00 & 0.00 & 2.90 & -3.16 & + & 0.37 & & & \\
\hline
\end{tabular}


Table 9. Ambystoma maculatum Abundance Models

Ambystoma maculatum (AMAC) abundance models ranked from best to worst. Detection covariates are day of year (DOY), and day of year squared $\left(\mathrm{DOY}^{2}\right)$. Abundance covariates were wetland age, conductivity $\left(\mu \mathrm{S} \mathrm{cm}^{-1}\right)$, conductivity ${ }^{2}\left(\mu \mathrm{S} \mathrm{cm}^{-1}\right)$, vegetation cover $(\%)$, and canopy cover $(\%)$.

\begin{tabular}{|c|c|c|c|c|c|c|c|c|c|c|c|}
\hline df & AIC & $\begin{array}{c}\text { Delta } \\
\text { AIC }\end{array}$ & $\begin{array}{c}\text { Model } \\
\text { Likelihood }\end{array}$ & $\begin{array}{c}\text { AIC } \\
\text { Weight }\end{array}$ & DOY & DOY $^{2}$ & Age & Conductivity & Conductivity $^{2}$ & $\begin{array}{c}\text { Vegetation } \\
\text { Cover }\end{array}$ & $\begin{array}{c}\text { Canopy } \\
\text { Cover }\end{array}$ \\
\hline 9 & 496.56 & 0.00 & 1.00 & 1.00 & 1.58 & -1.66 & + & 1.34 & -0.97 & & \\
\hline 8 & 549.74 & 53.18 & 0.00 & 0.00 & 1.63 & -1.73 & + & 0.90 & & & \\
\hline 8 & 562.25 & 65.69 & 0.00 & 0.00 & 1.66 & -1.77 & + & & & 0.36 & \\
\hline 7 & 571.26 & 74.70 & 0.00 & 0.00 & 1.68 & -1.79 & + & & & & \\
\hline 8 & 572.58 & 76.03 & 0.00 & 0.00 & 1.68 & -1.79 & + & & & & -0.11 \\
\hline 5 & 628.34 & 131.78 & 0.00 & 0.00 & 1.71 & -1.85 & & & & & 0.29 \\
\hline 6 & 629.65 & 133.09 & 0.00 & 0.00 & 1.73 & -1.88 & & -0.02 & -0.40 & & \\
\hline 4 & 641.37 & 144.81 & 0.00 & 0.00 & 1.73 & -1.88 & & & & & \\
\hline 5 & 641.55 & 145.00 & 0.00 & 0.00 & 1.73 & -1.87 & & & & 0.14 & \\
\hline 5 & 642.65 & 146.10 & 0.00 & 0.00 & 1.73 & -1.88 & & -0.11 & & & \\
\hline
\end{tabular}


Table 10. Notophthalmus viridescens Abundance Models

Notophthalmus viridescens (NVIR) abundance models ranked from best to worst. Detection covariates are day of year (DOY), and day of year squared $\left(\mathrm{DOY}^{2}\right)$. Abundance covariates were wetland age, conductivity $\left(\mu \mathrm{S} \mathrm{cm}^{-1}\right)$, conductivity ${ }^{2}\left(\mu \mathrm{S} \mathrm{cm}{ }^{-1}\right)$, vegetation cover $(\%)$, and canopy cover $(\%)$.

\begin{tabular}{|c|c|c|c|c|c|c|c|c|c|c|}
\hline df & AIC & $\begin{array}{c}\text { Delta } \\
\text { AIC }\end{array}$ & $\begin{array}{c}\text { Model } \\
\text { Likelihood }\end{array}$ & $\begin{array}{c}\text { AIC } \\
\text { Weight }\end{array}$ & DOY & DOY & Age & Conductivity & $\begin{array}{c}\text { Vegetation } \\
\text { Conductivity }\end{array}$ & $\begin{array}{c}\text { Canopy } \\
\text { Cover }\end{array}$ \\
\hline 9 & 614.05 & 0.00 & 1.00 & 1.00 & 0.10 & -0.26 & + & & -0.79 \\
\hline 10 & 625.39 & 11.34 & 0.00 & 0.00 & 0.09 & -0.27 & + & 0.73 & \\
\hline 9 & 650.42 & 36.37 & 0.00 & 0.00 & 0.10 & -0.27 & + & & \\
\hline 9 & 651.96 & 37.91 & 0.00 & 0.00 & 0.10 & -0.27 & + & 0.49 & \\
\hline 8 & 654.52 & 40.47 & 0.00 & 0.00 & 0.10 & -0.27 & + & & \\
\hline 7 & 708.82 & 94.77 & 0.00 & 0.00 & 0.11 & -0.29 & & -0.42 & -0.27 & \\
\hline 6 & 709.33 & 95.28 & 0.00 & 0.00 & 0.12 & -0.29 & & -0.53 & \\
\hline 6 & 721.46 & 107.41 & 0.00 & 0.00 & 0.12 & -0.29 & & & \\
\hline 5 & 731.69 & 117.64 & 0.00 & 0.00 & 0.11 & -0.30 & & & \\
\hline 6 & 733.28 & 119.23 & 0.00 & 0.00 & 0.11 & -0.30 & & & \\
\hline
\end{tabular}


Table 11. Lithobates clamitans Abundance Models

Lithobates clamitans (LCLA) abundance models ranked from best to worst. Detection covariates are day of year (DOY), and day of year squared $\left(\mathrm{DOY}^{2}\right)$. Abundance covariates were wetland age, conductivity $\left(\mu \mathrm{S} \mathrm{cm}^{-1}\right)$, conductivity ${ }^{2}\left(\mu \mathrm{S} \mathrm{cm}{ }^{-1}\right)$, vegetation cover $(\%)$, and canopy cover (\%).

\begin{tabular}{|c|c|c|c|c|c|c|c|c|c|c|c|}
\hline df & AIC & Delta AIC & $\begin{array}{c}\text { Model } \\
\text { Likelihood }\end{array}$ & $\begin{array}{c}\text { AIC } \\
\text { Weight }\end{array}$ & DOY & DOY $^{2}$ & Age & Conductivity & Conductivity $^{2}$ & $\begin{array}{l}\text { Vegetation } \\
\text { Cover }\end{array}$ & $\begin{array}{c}\text { Canopy } \\
\text { Cover }\end{array}$ \\
\hline 5 & 750.7 & 0 & 1 & 0.2476 & -0.37 & 0.21 & & & & & \\
\hline 6 & 750.8 & 0.099345 & 0.951541 & 0.2356 & -0.37 & 0.21 & & & & & -0.58 \\
\hline 6 & 751.4 & 0.728798 & 0.694614 & 0.172 & -0.37 & 0.21 & & & & 0.34 & \\
\hline 8 & 751.5 & 0.808162 & 0.66759 & 0.1653 & -0.37 & 0.21 & + & & & & \\
\hline 6 & 753.5 & 2.765956 & 0.25083 & 0.0621 & -0.37 & 0.21 & & -0.04 & & & \\
\hline 9 & 754.7 & 4.05513 & 0.131656 & 0.0326 & -0.37 & 0.21 & + & & & -0.16 & \\
\hline 9 & 754.8 & 4.072409 & 0.130523 & 0.0323 & -0.37 & 0.21 & + & -0.11 & & & \\
\hline 9 & 754.8 & 4.124012 & 0.127199 & 0.0315 & -0.37 & 0.21 & + & & & & -0.07 \\
\hline 7 & 756.3 & 5.638102 & 0.059663 & 0.0148 & -0.37 & 0.21 & & 0.04 & -0.08 & & \\
\hline 10 & 758 & 7.356779 & 0.025264 & 0.0063 & -0.37 & 0.21 & + & 0.02 & -0.14 & & \\
\hline
\end{tabular}


Table 12. Lithobates sylvaticus Abundance Models

Lithobates sylvaticus (LSYL) abundance models ranked from best to worst. Detection covariates are day of year (DOY), and day of year squared $\left(\mathrm{DOY}^{2}\right)$. Abundance covariates were wetland age, conductivity $\left(\mu \mathrm{S} \mathrm{cm}^{-1}\right)$, conductivity $\left(\mu \mathrm{S} \mathrm{cm}{ }^{-1}\right)$, vegetation cover $(\%)$, and canopy cover $(\%)$.

\begin{tabular}{|c|c|c|c|c|c|c|c|c|c|c|c|}
\hline df & AIC & $\begin{array}{c}\text { Delta } \\
\text { AIC }\end{array}$ & $\begin{array}{c}\text { Model } \\
\text { Likelihood }\end{array}$ & $\begin{array}{c}\text { AIC } \\
\text { Weight }\end{array}$ & DOY & DOY $^{2}$ & Age & Conductivity & Conductivity $^{2}$ & $\begin{array}{c}\text { Vegetation } \\
\text { Cover }\end{array}$ & $\begin{array}{c}\text { Canopy } \\
\text { Cover }\end{array}$ \\
\hline 6 & 292.81 & 0.00 & 1.00 & 0.27 & -0.62 & -0.57 & & 1.32 & & & \\
\hline 5 & 292.86 & 0.06 & 0.97 & 0.26 & -0.62 & -0.57 & & & & & \\
\hline 7 & 293.30 & 0.49 & 0.78 & 0.21 & -0.62 & -0.57 & & 2.60 & -1.97 & & \\
\hline 6 & 294.46 & 1.65 & 0.44 & 0.12 & -0.62 & -0.57 & & & & & -0.98 \\
\hline 6 & 295.63 & 2.82 & 0.24 & 0.07 & -0.62 & -0.57 & & & & 0.14 & \\
\hline 8 & 296.56 & 3.75 & 0.15 & 0.04 & -0.62 & -0.57 & + & & & & \\
\hline 9 & 299.84 & 7.03 & 0.03 & 0.01 & -0.62 & -0.57 & + & & & 0.30 & \\
\hline 9 & 299.91 & 7.11 & 0.03 & 0.01 & -0.62 & -0.57 & + & & & & 0.03 \\
\hline 9 & 299.92 & 7.11 & 0.03 & 0.01 & -0.62 & -0.57 & + & -0.02 & & & \\
\hline 10 & 300.40 & 7.59 & 0.02 & 0.01 & -0.62 & -0.57 & + & -0.47 & -2.51 & & \\
\hline
\end{tabular}




\section{FIGURES}

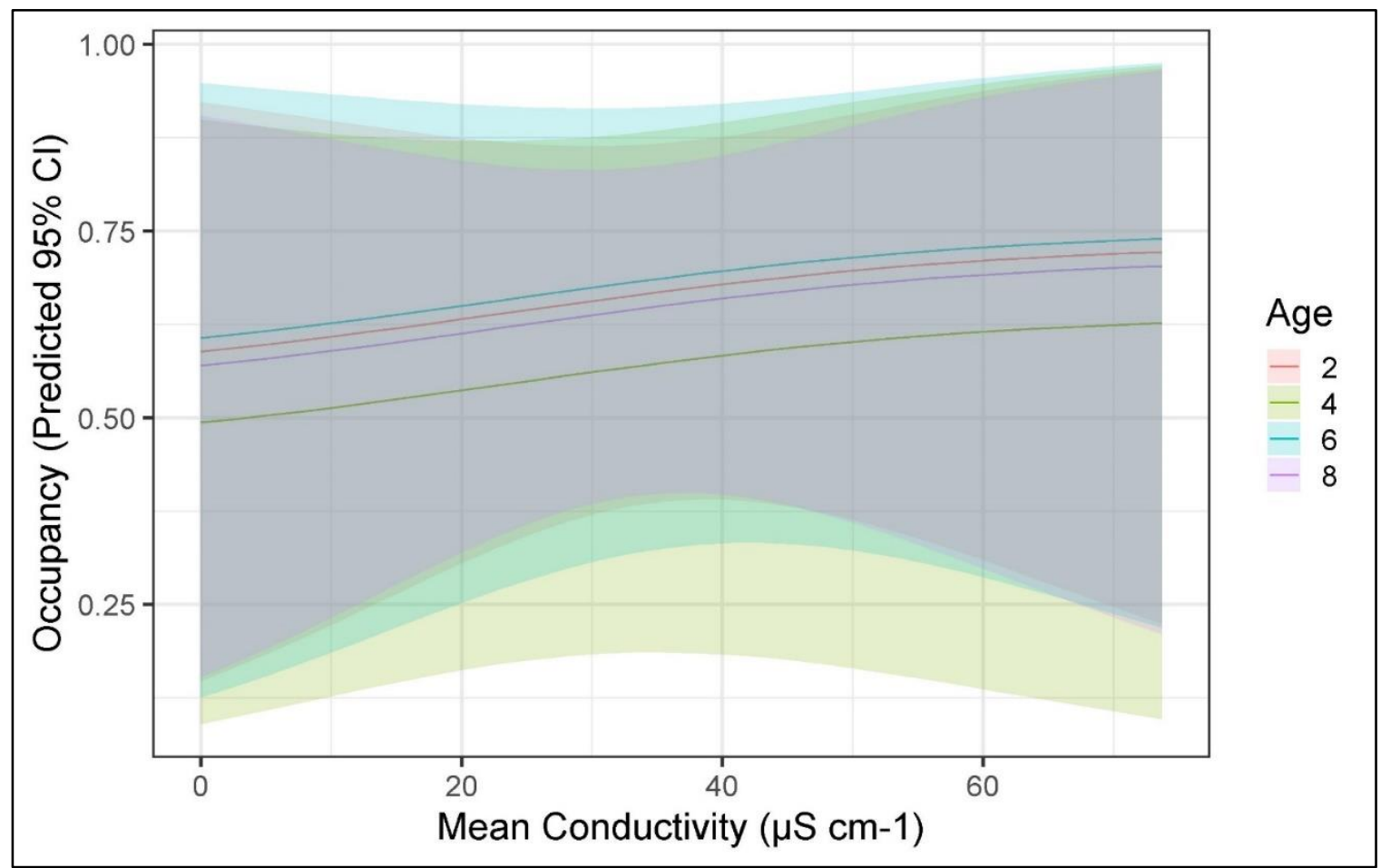

\section{Figure 1. Ambystoma maculatum Occupancy and Mean Conductivity}

Ambystoma maculatum model predicted occupancy and $95 \%$ confidence intervals $(95 \% \mathrm{CI})$ at mean conductivity $\left(\mu \mathrm{S} \mathrm{cm}^{-1}\right)$ for each age class. Confidence intervals are represented with color bands. 


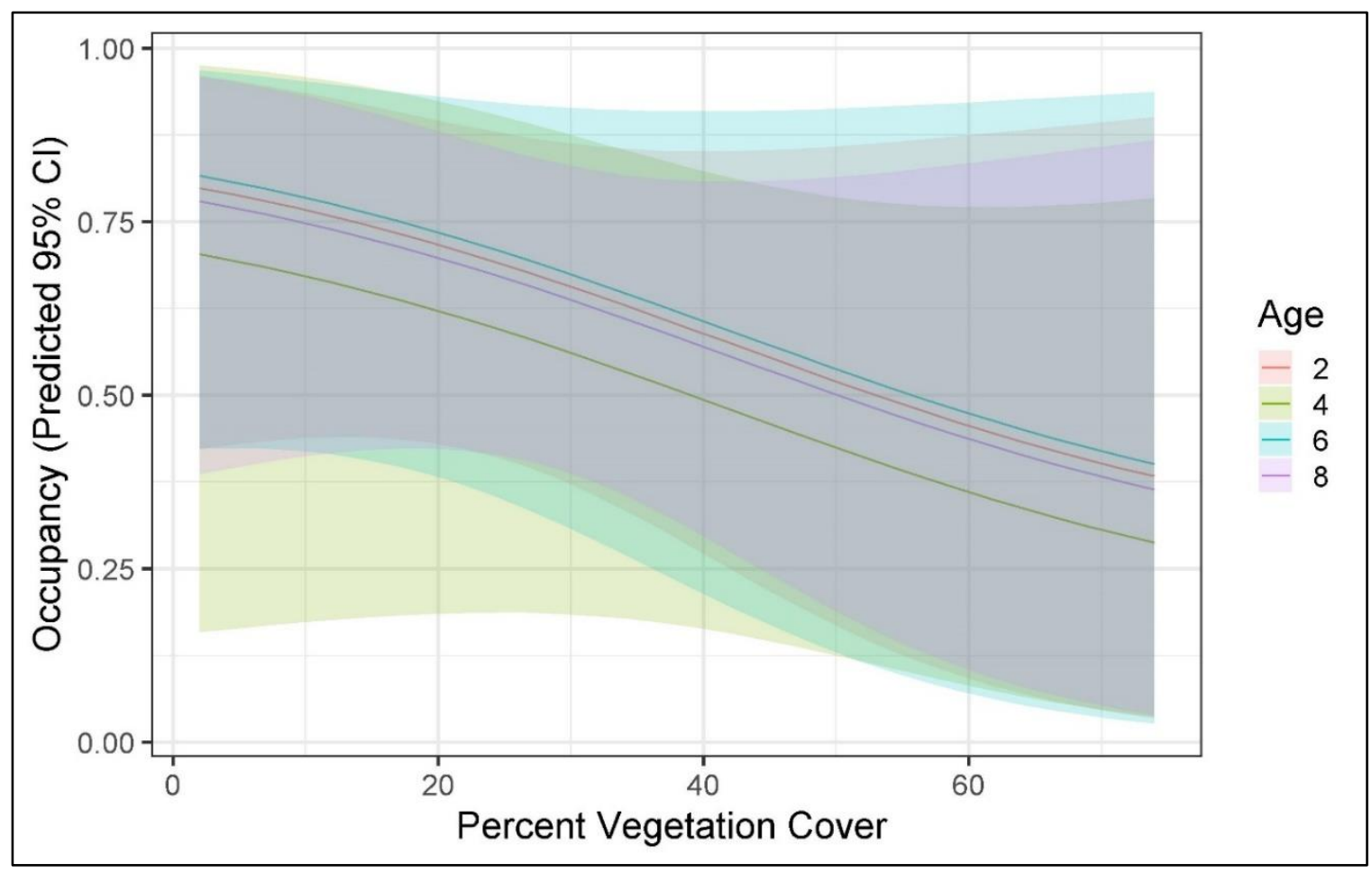

\section{Figure 2. Ambystoma maculatum Occupancy and Percent Vegetation Cover}

Ambystoma maculatum model predicted occupancy and 95\% confidence intervals $(95 \% \mathrm{CI})$ at percent vegetation cover for each age class. Confidence intervals are represented with color bands. 


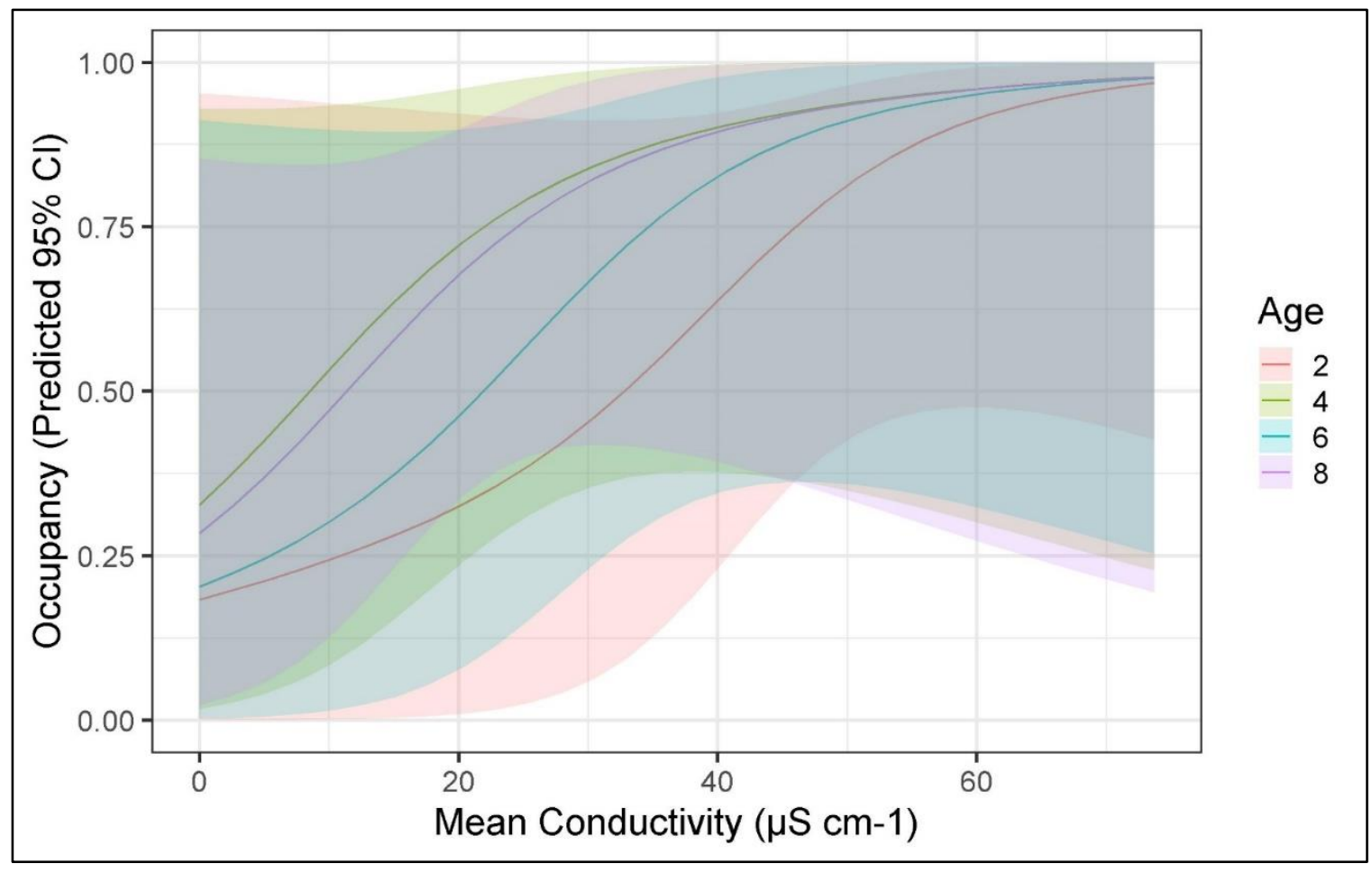

\section{Figure 3. Notophthalmus viridescens Occupancy and Mean Conductivity}

Notophthalmus viridescens model predicted occupancy and $95 \%$ confidence intervals $(95 \% \mathrm{CI})$ at mean conductivity $\left.(\mu \mathrm{S} \mathrm{cm})^{-1}\right)$ Confidence intervals are represented with color bands. 




Figure 4. Lithobates clamitans Occupancy and Percent Vegetation Cover

Lithobates clamitans model predicted occupancy and 95\% confidence intervals (95\% CI) at percent vegetation cover for each age class. Confidence intervals are represented with color bands. 


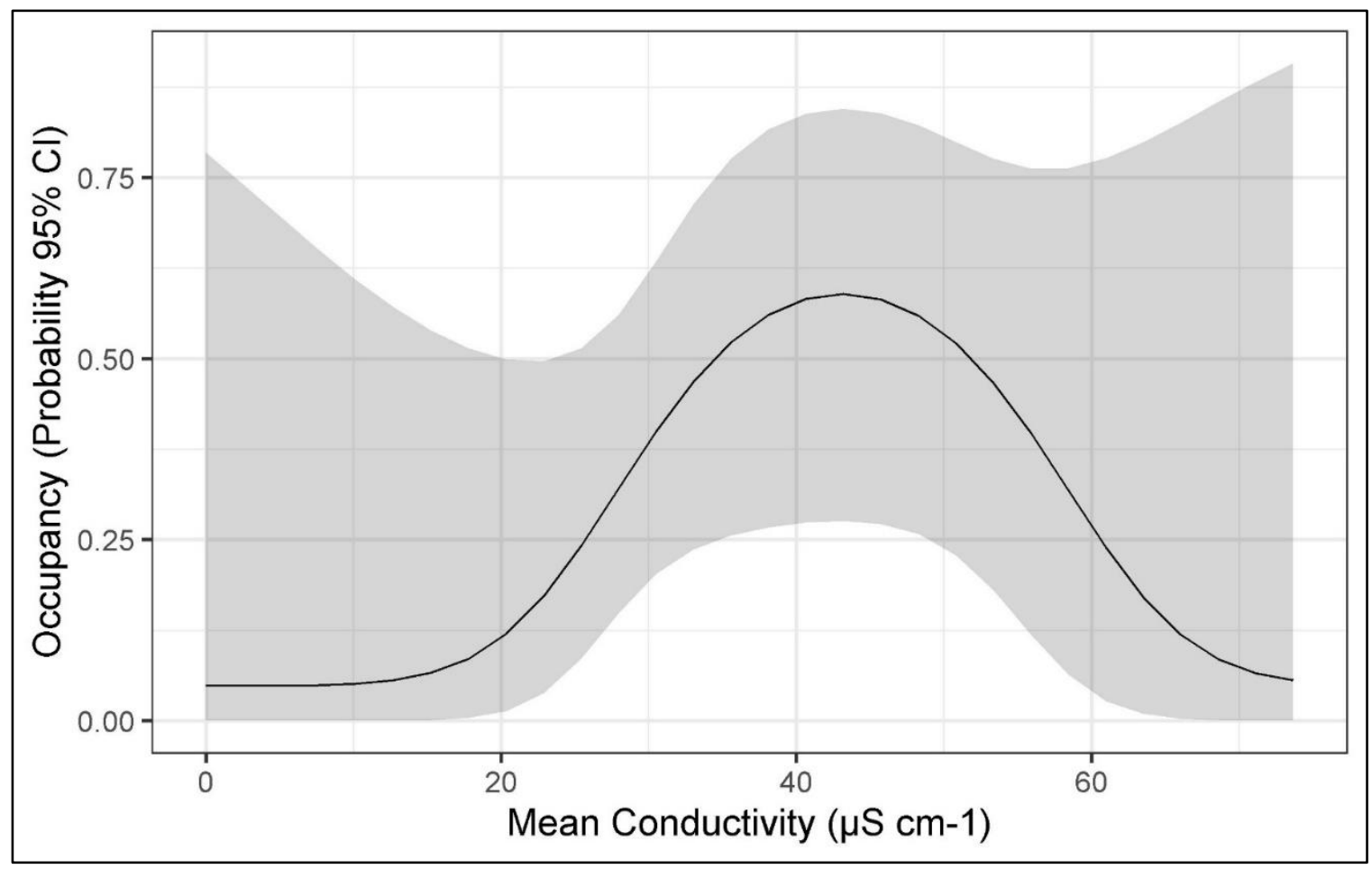

\section{Figure 5. Pseudacris crucifer Occupancy and Mean Conductivity}

Pseudacris crucifer model predicted occupancy and 95\% confidence interval (95\% CI) at mean conductivity $\left(\mu \mathrm{S} \mathrm{cm}{ }^{-1}\right)$. Confidence interval is represented by gray band. 


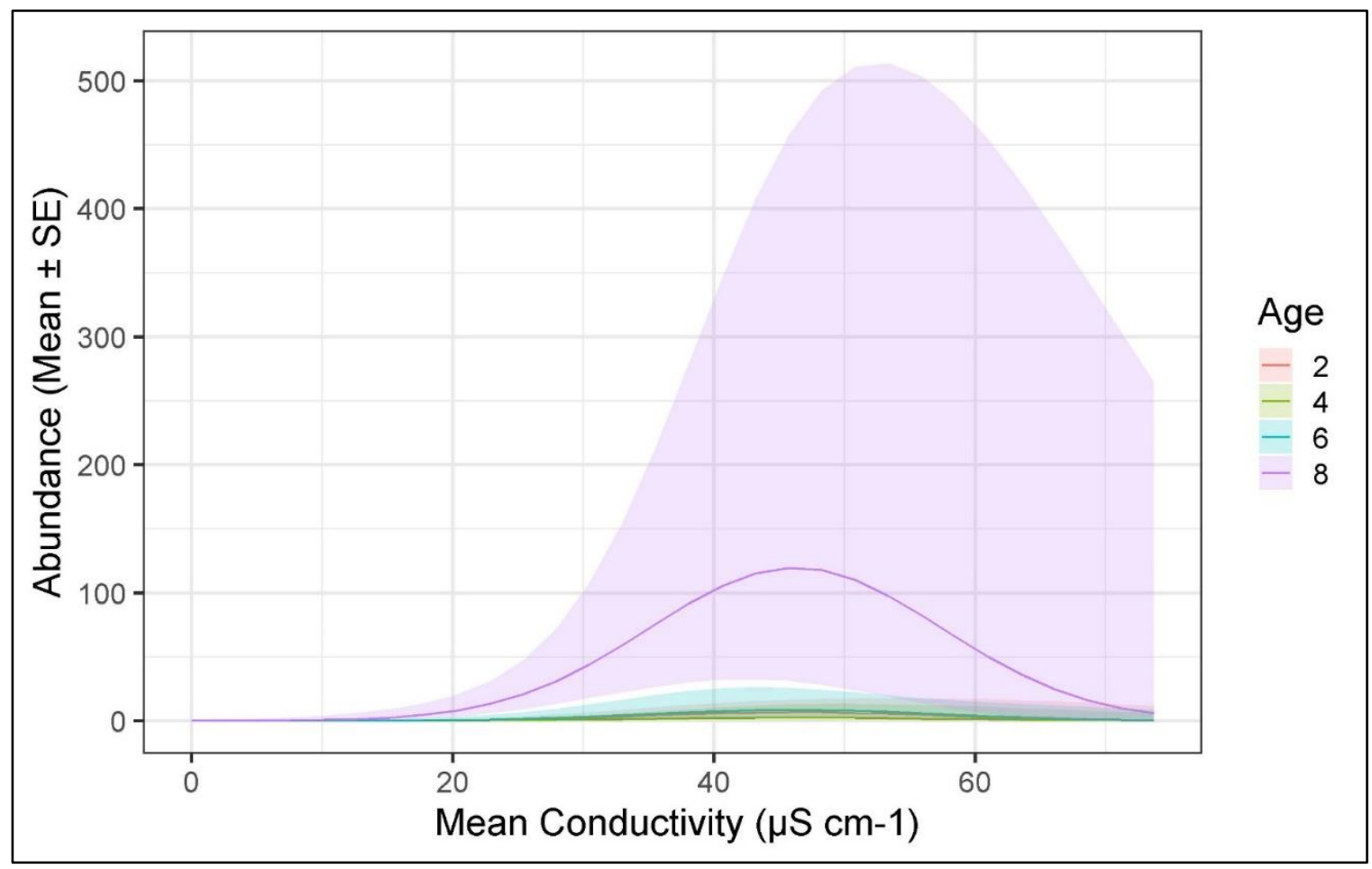

\section{Figure 6. Ambystoma maculatum Abundance and Mean Conductivity}

Ambystoma maculatum mean model predicted abundance and standard error (SE) at mean conductivity $\left(\mu \mathrm{S} \mathrm{cm}{ }^{-1}\right)$ for each age class. Standard error is represented with color bands. 


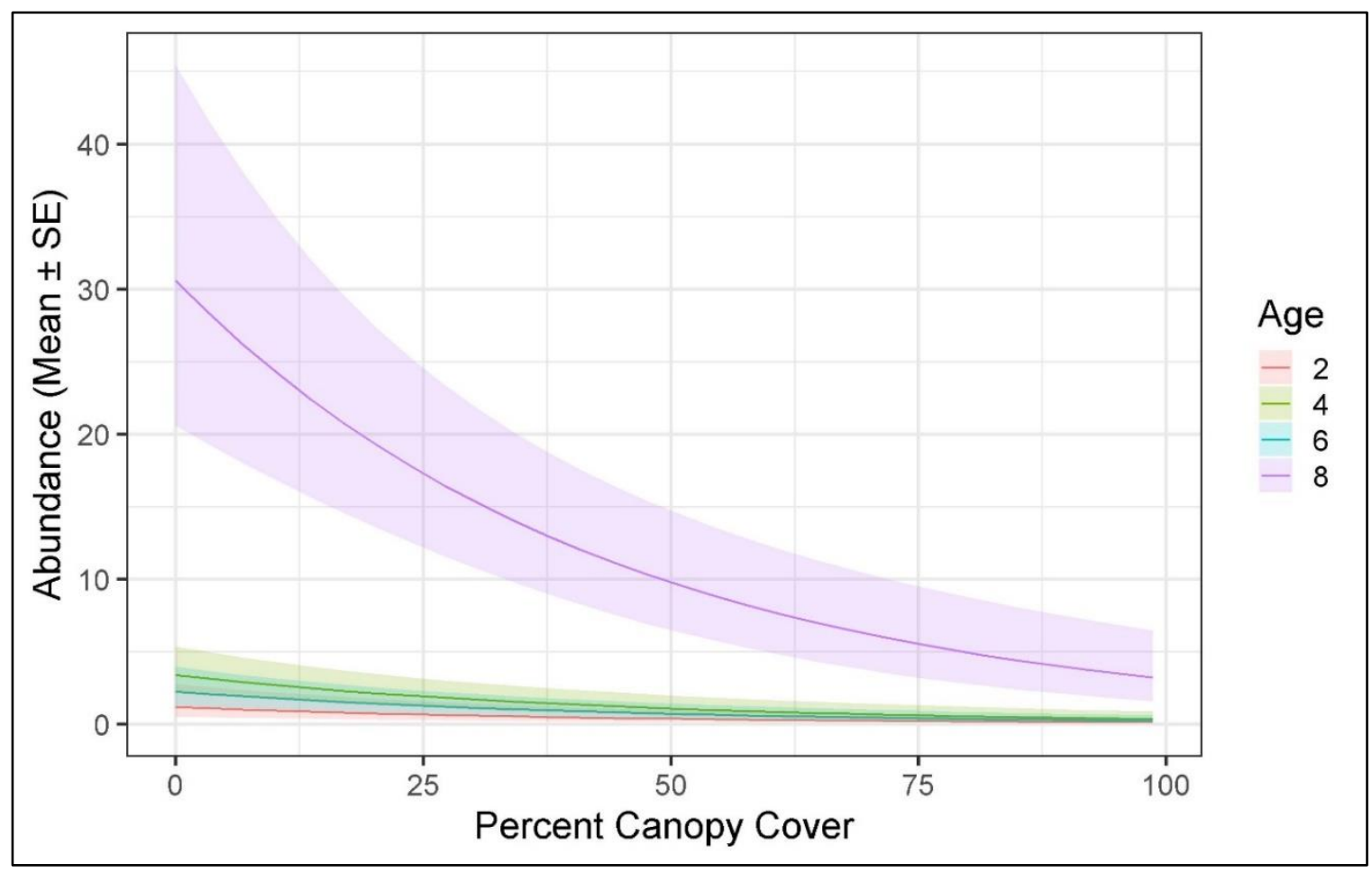

\section{Figure 7. Notophthalmus viridescens Abundance and Percent Canopy Cover}

Notophthalmus viridescens mean model predicted abundance and standard error (SE) at percent canopy cover for each age class. Standard error is represented with color bands. 


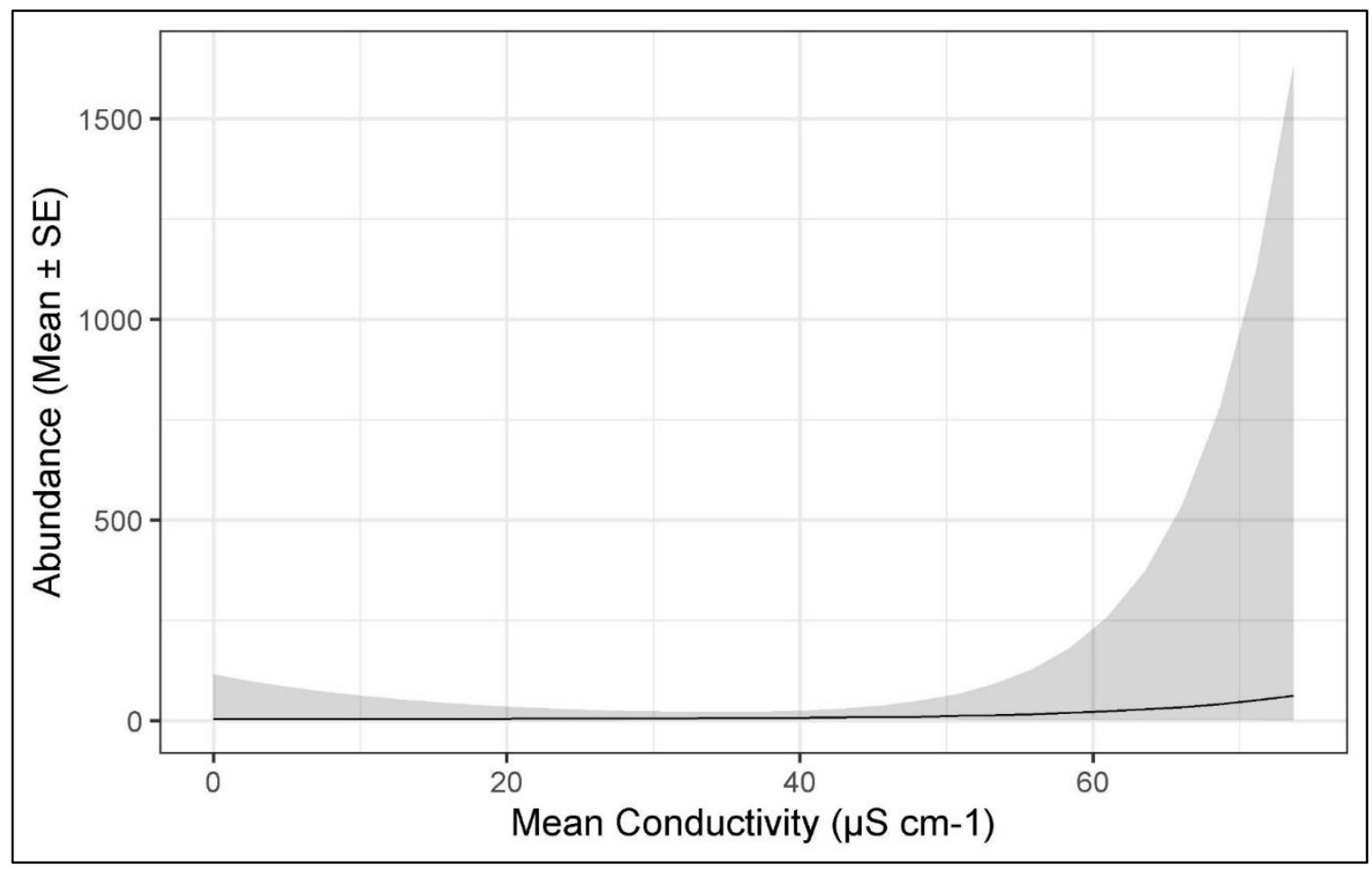

\section{Figure 8. Lithobates sylvaticus Abundance and Mean Conductivity}

Lithobates sylvaticus mean model predicted abundance and standard error (SE) at mean conductivity $\left(\mu \mathrm{S} \mathrm{cm}{ }^{-1}\right)$. Standard error is represented by the gray band. 


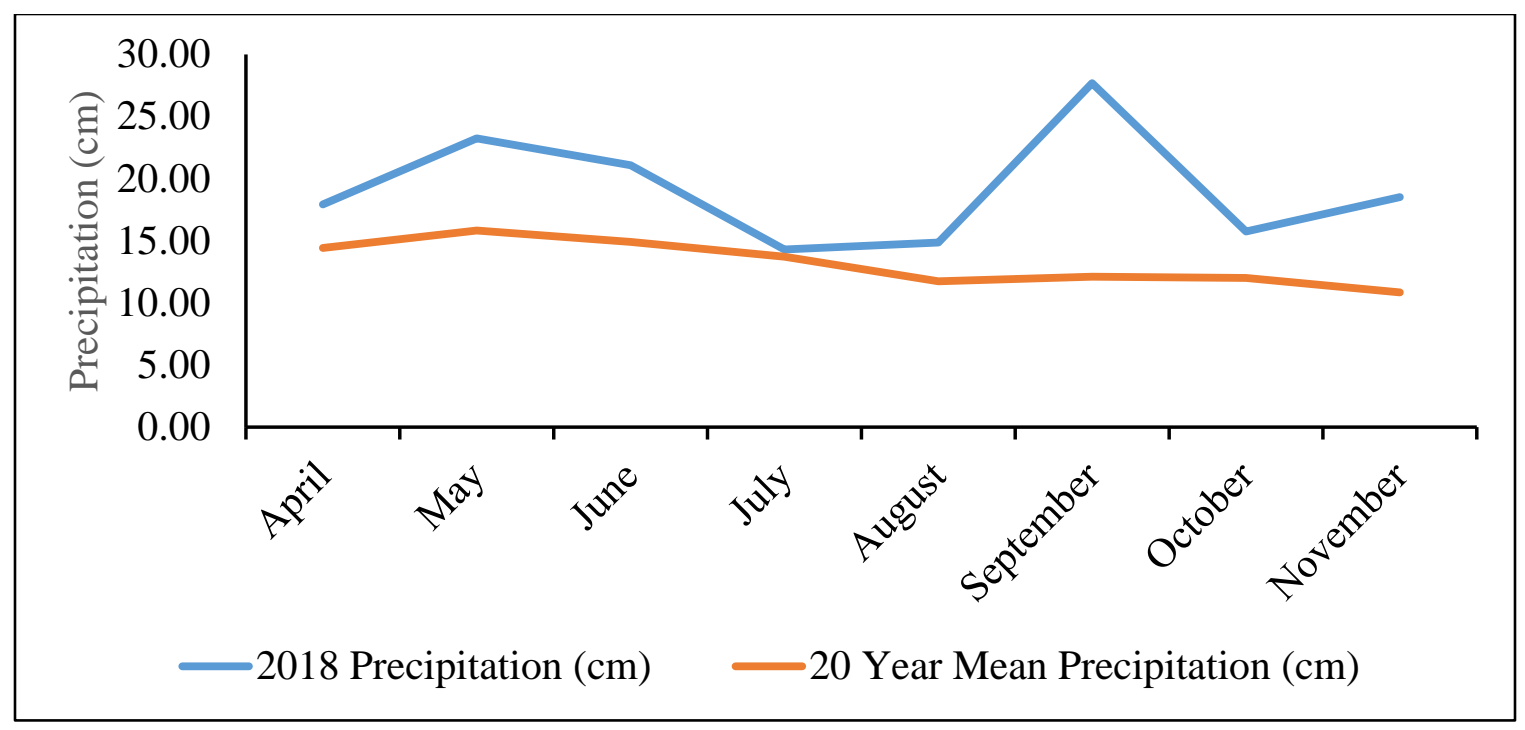

Figure 9. 2018 Vs 20 Year Mean Precipitation

Monthly 2018 and 20 year mean precipitation (cm) April through November. 


\section{REFERENCES}

Adams, M. B. (1999). Acidic deposition and sustainable forest management in the central Appalachians, USA. Forest Ecology and Management, 122(1-2), 17-28.

Adams, M. B., Angradi, T. R., \& Kochenderfer, J. N. (1997). Stream water and soil solution responses to 5 years of nitrogen and sulfur additions at the Fernow Experimental Forest, West Virginia. Forest Ecology and Management, 95(1), 7991.

Adams, M. B., Burger, J. A., Jenkins, A. B., \& Zelazny, L. (2000). Impact of harvesting and atmospheric pollution on nutrient depletion of eastern US hardwood forests. Forest Ecology and Management, 138(1-3), 301-319.

Adams, M. B., \& Eagar, C. (1992). Impacts of acidic deposition on high-elevation spruce-fir forests: results from the Spruce-Fir Research Cooperative. Forest Ecology and Management, 51(1-3), 195-205.

Andersen, C. P., Bussler, B. H., Chaney, W. R., Pope, P. E., \& Byrnes, W. R. (1989). Concurrent establishment of ground cover and hardwood trees on reclaimed mined land and unmined reference sites. Forest Ecology and Management, 28(2), 81-99.

Batzer, D. P., \& Sharitz, R. R. (Eds.). (2014). Ecology of freshwater and estuarine wetlands. University of California Press.

Bernhardt, E. S., \& Palmer, M. A., (2011). The environmental costs of mountaintop mining valley fill operations for aquatic ecosystems of the Central Appalachians. Annals of the New york Academy of Sciences, 1223(1), 39-57.

Birx-Raybuck, D. A., Price, S. J., \& Dorcas, M. E. (2010). Pond age and riparian zone proximity influence anuran occupancy of urban retention ponds. Urban Ecosystems, 13(2), 181-190.

Brodman, R., Parrish, M., Kraus, H., \& Cortwright, S. (2006). Amphibian biodiversity recovery in a large-scale ecosystem restoration. Herpetological Conservation and Biology, 1(2), 101-108.

Brown, D. J., Street, G. M., Nairn, R. W., \& Forstner, M. R. (2012). A place to call home: amphibian use of created and restored wetlands. International Journal of Ecology, 2012(2012), 11.

Burnham, K. P., \& Anderson, D. R.(2002). Information and likelihood theory: a basis for model selection and inference. Model selection and multimodel inference: a practical information-theoretic approach, 49-97.

Byers, E. A., Vanderhorst, J. P., \& Streets, B. P. (2010). Classification and conservation assessment of upland red spruce communities in West Virginia. WV Natural Heritage Program, WVDNR, Wildlife Resources Section, Elkins, WV. 
Byers, E. A., Vanderhorst, J. P., \& Streets, B. P. (2007). Classification and conservation assessment of high elevation wetland communities in the Allegheny Mountains of West Virginia. WV Natural Heritage Program, WVDNR, Wildlife Resources Section, Elkins, $W V$.

Calhoun, A. J., Arrigoni, J., Brooks, R. P., Hunter, M. L., \& Richter, S. C. (2014). Creating successful vernal pools: a literature review and advice for practitioners. Wetlands, 34(5), 1027-1038.

Chambers, D. L. (2011). Increased conductivity affects corticosterone levels and prey consumption in larval amphibians. Journal of Herpetology, 45(2), 219-223.

Clark, K. L. (1986). Distributions of anuran populations in central Ontario relative to habitat acidity. Water, Air, and Soil Pollution, 30(3-4), 727-734.

Costanza, R., D'Arge, R., De Groot, R., Farber, S., Grasso, M., Hannon, B., Limburg, K., Neem, S., O’Neill, R. V., Paruelo, J., Raskin, R. G., Sutton, P., \& Van Den Belt, M. (1997). The value of the world's ecosystem services and natural capital. nature, 387(6630), 253-260.

Dahl, T. E. (2005). Status and trends of wetlands in the conterminous United States 1998 to 2004. US Department of the Interior, US Fish and Wildlife Service, Fisheries and Habitat Conservation, Washington D.C..

Dahl, T. E. (2011). Status and trends of wetlands in the conterminous United States 2004 to 2009. US Department of the Interior, US Fish and Wildlife Service, Fisheries and Habitat Conservation, Washington D.C..

Deano, P. M., \& Robinson, J. W. (1985). The effect of decaying leaves on the ph and buffer capacity of waters. Journal of Environmental Science \& Health Part A, 20(8), 903-911.

Denton, R. D., \& Richter, S. C. (2013). Amphibian communities in natural and constructed ridge top wetlands with implications for wetland construction. The Journal of Wildlife Management, 77(5), 886-896.

Drayer, A. N., \& Richter, S. C. (2016). Physical wetland characteristics influence amphibian community composition differently in constructed wetlands and natural wetlands. Ecological Engineering, 93(2016), 166-174.

Driscoll, C. T., Lawrence, G. B., Bulger, A. J., Butler, T. J., Cronan, C. S., Eagar, C., ... \& Weathers, K. C. (2001). Acidic Deposition in the Northeastern United States: Sources and Inputs, Ecosystem Effects, and Management Strategies: The effects of acidic deposition in the northeastern United States include the acidification of soil and water, which stresses terrestrial and aquatic biota. BioScience, 51(3), 180198.

ESRI. (2013). ArcMAP Desktop, Release 10.5.1. Redlands, CA: Environmental Systems Research Institute.

Fiske, I., \& Chandler, R. (2011). Unmarked: an R package for fitting hierarchical models of wildlife occurrence and abundance. Journal of Statistical Software, 43(10), 123. 
Franklin, J. A., Zipper, C. E., Burger, J. A., Skousen, J. G., \& Jacobs, D. F. (2012). Influence of herbaceous ground cover on forest restoration of eastern US coal surface mines. New Forests, 43(5-6), 905-924.

Gibbons, J. W., Winne, C. T., Scott, D. E., Willson, J. D., Glaudas, X., Andrews, K. M., Todd, B. D., Fedewa, L.A., Wilkinson, L., Tsaliagos, S. J., Harper, S. J., Greene, J. L., Tuberville, T. D., Metts, B, S,. Dorcas, M. E., Nestor, J. P., Young, C. A., Akre, A., Reed, R. N., Buhlmann, K. A., Norman, J., Croshaw, D.A., Hagen, C., \& Rothermel, B. B. (2006). Remarkable amphibian biomass and abundance in an isolated wetland: implications for wetland conservation. Conservation Biology, 20(5), 1457-1465.

Gopal, B., \& Junk, W. J. (2000). Biodiversity in wetlands: an introduction. Biodiversity in wetlands: assessment, function and conservation. Vol. 1 (pp. 1-10). Backhuys Publishers.

Greenhouse, S. W., \& Geisser, S. (1959). On methods in the analysis of profile data. Psychometrika, 24(2), 95-112.

Grant, E. H. C., Miller, D. A., Schmidt, B. R., Adams, M. J., Amburgey, S. M., Chambert, T., Cruickshank, S. S., Fisher, R. N., Green, D. M., Hossack B. R., Johnson, P. T., Joseph, M.B., Rittenhouse, T. A. G., Ryan, M. E., Waddle, H., Walls, S. C., Bailey L.L., Fellers, G. M., Gorman, T. A., Ray, A.M., Pilloid D. S., Price, S. J., Saenz, D., Sadinski W., \& Muths E. (2016). Quantitative evidence for the effects of multiple drivers on continental-scale amphibian declines. Scientific Reports, 6(1), 1-9.

Greenberg, A. E., Clesceri, L. S., \& Eaton, A. D. (1992). Standard methods for the examination of water and wastewater. American Public Health Association.

Hamer, A. J., Heard, G. W., Urlus, J., Ricciardello, J., Schmidt, B., Quin, D., \& Steele, W. K. (2016). Manipulating wetland hydroperiod to improve occupancy rates by an endangered amphibian: modelling management scenarios. Journal of Applied Ecology, 53(6), 1842-1851.

Hanski, I., \& Gilpin, M. (1991). Metapopulation dynamics: brief history and conceptual domain. Biological journal of the Linnean Society, 42(1-2), 3-16.

Hargreaves, J. A. (1998). Nitrogen biogeochemistry of aquaculture ponds. Aquaculture, 166(3-4), 181-212.

Hughes, J. (Ed.). (2018). Freshwater ecology and conservation: approaches and techniques. Oxford University Press.

Hurvich, C. M., \& Tsai, C. L. (1989). Regression and time series model selection in small samples. Biometrika, 76(2), 297-307.

Hutton J. M. (2018). Diet composition explains reductions in stream salamander occupancy and abundance along a Conductivity Gradient. [Masters Thesis, University of Kentucky]. Theses and Dissertations-Forestry. 
Hutton, J.M., S.J. Price, S.J. Bonner, S.C. Richter and C.D. Barton. In press. Occupancy and abundance of stream salamanders along a specific conductance gradient. Freshwater Science.

Karraker, N. E., Gibbs, J. P., \& Vonesh, J. R. (2008). Impacts of road deicing salt on the demography of vernal pool-breeding amphibians. Ecological Applications, 18(3), 724-734.

Kross, C. S., \& Richter, S. C. (2016). Species interactions in constructed wetlands result in population sinks for wood frogs (Lithobates sylvaticus) while benefiting eastern newts (Notophthalmus viridescens). Wetlands, 36(2), 385-393.

Kudray, G. M., \& Schemm, T. (2008). Wetlands of the Bitterroot Valley: Change and ecological functions. Montana Natural Heritage Program.

Kutka, F. J., \& Bachmann, M. D. (1990). Acid sensitivity and water chemistry correlates of amphibian breeding ponds in northern Wisconsin, USA. Hydrobiologia, 208(3), 153-160.

Laan, R., \& Verboom, B. (1990). Effects of pool size and isolation on amphibian communities. Biological Conservation, 54(3), 251-262.

Lannoo, Michael, \& Lannoo, M. (2005). Amphibian Declines: The Conservation Status of United States Species. University of California Press.

Lannoo, M. J., Kinney, V. C., Heemeyer, J. L., Engbrecht, N. J., Gallant, A. L., \& Klaver, R. W. (2009). Mine spoil prairies expand critical habitat for endangered and threatened amphibian and reptile species. Diversity, 1(2), 118-132.

Lehtinen, R. M., \& Galatowitsch, S. M. (2001). Colonization of restored wetlands by amphibians in Minnesota. The American Midland Naturalist, 145(2), 388-396.

Loughman, Z. J. (2005). Natural History and Conservation Biology of a Southern West Virginia Contour Surface Mine Reptile and Amphibian Community. (Paper 709). [Masters Thesis, Marshall University]. Marshall Digital Scholar.

MacKenzie, D. I., J. D. Nichols, G. B. Lachman, S. Droege, J. Andrew Royle, and C. A. Langtimm. 2002. Estimating site occupancy rates when detection probabilities are less than one. Ecology, 83, 2248-2255.

Marsh, D. M., Fegraus, E., \& Harrison, S. (1999). Effects of breeding pond isolation on the spatial and temporal dynamics of pond use by the tungara frog, Physalaemus pustulosus. Journal of Animal Ecology, 68(4), 804-814.

Mathias, J. M., \& Thomas, R. B. (2018). Disentangling the effects of acidic air pollution, atmospheric $\mathrm{CO} 2$, and climate change on recent growth of red spruce trees in the Central Appalachian Mountains. Global change biology, 24(9), 3938-3953.

Mazerolle, M. J. (2016). AICcmodavg: model selection and multimodel inference based on (Q) AIC (c). R package ver. 2.2-2. URL: https://cran. r-project. org/package= AICcmodavg, consulté le, 6(03), 2019. 
Millikin, A. R., Woodley, S. K., Davis, D. R., \& Anderson, J. T. (2019). Habitat characteristics in created vernal pools impact spotted salamander water-borne corticosterone levels. Wetlands, 39(4), 803-814.

Minkin, P., \& Ladd, R. (2003). Success of corps-required wetland mitigation in New England. Concord, MA: US Army Corps of Engineers, Boston MA, New England District. April.

Muncy B. L., Price, S. J., Bonner, S. J., \& Barton, C. D. (2014). Mountaintop removal mining reduces stream salamander occupancy and richness in southeastern Kentucky (USA). Biological Conservation, 180(2014), 115-121.

National Weather Service Forecast Office of Charleston, WV; NOWData for Snowshoe, WV; https://w2.weather.gov/climate/xmacis.php?wfo=rlx (accessed 1-23-2020)

Plass, W. T. (1982). The impact of surface mining on the commercial forests of the United States. Post-mining productivity with trees, 31(1982), 1-7.

Porej, D., \& Hetherington, T. E. (2005). Designing wetlands for amphibians: the importance of predatory fish and shallow littoral zones in structuring of amphibian communities. Wetlands Ecology and Management, 13(4), 445-455.

Price, S. J., Freytag, S. B., Bonner, S. J., Drayer, A. N., Muncy, B. L., Hutton, J. M., \& Barton, C. D. (2018). Mountaintop removal mining alters stream salamander population dynamics. Diversity and Distributions, 24(9), 1242-1251.

Price, S. J., Freytag, S. B., Bonner, S. J., Drayer, A. N., Muncy, B. L., Hutton, J. M., \& Barton, C. D. (2018). Mountaintop removal mining alters stream salamander population dynamics. Diversity and Distributions, 24(9), 1242-1251.

Price, S. J., Muncy, B. L., Bonner, S. J., Drayer, A. N., \& Barton, C. D. (2016). Effects of mountaintop removal mining and valley filling on the occupancy and abundance of stream salamanders. Journal of Applied Ecology, 53(2), 459-468.

Reddy, K. R., Patrick Jr, W. H., \& Lindau, C. W. (1989). Nitrification-denitrification at the plant root-sediment interface in wetlands. Limnology and oceanography, 34(6), 1004-1013.

Royle, J. A. (2004). N-mixture models for estimating population size from spatially replicated counts. Biometrics, 60(1), 108-115.

Ryan, P. F., Hornberger, G. M., Cosby, B. J., Galloway, J. N., Webb, J. R., \& Rastetter, E. B. (1989). Changes in the chemical composition of stream water in two catchments in the Shenandoah National Park, Virginia, in response to atmospheric deposition of sulfur. Water Resources Research, 25(10), 2091-2099.

Schielzeth, H. (2010). Simple means to improve the interpretability of regression coefficients. Methods in Ecology and Evolution, 1(2), 103-113.

Semlitsch, R. D., \& Bodie, J. R. (1998). Are small, isolated wetlands expendable?. Conservation biology, 12(5), 1129-1133.

Semlitsch, R. D. (2008). Moving wetland mitigation towards conservation banking. National Wetlands Newsletter, 30(5), 16. 
Semlitsch, R. D., Walls, S. C., Barichivich, W. J., \& O'Donnell, K. M. (2017). Extinction debt as a driver of amphibian declines: an example with imperiled flatwoods salamanders. Journal of herpetology, 51(1), 12-18.

Sena, K., Agouridis, C., Miller, J., \& Barton, C. (2018). Spoil type influences soil genesis and forest development on an Appalachian surface coal mine ten years after placement. Forests, 9(12), 780.

Sena, K., Barton, C., Angel, P., Agouridis, C., \& Warner, R. (2014). Influence of spoil type on chemistry and hydrology of interflow on a surface coal mine in the eastern US coalfield. Water, Air, \& Soil Pollution, 225(11), 2171.

Sena, K., Barton, C., Hall, S., Angel, P., Agouridis, C., \& Warner, R. (2015). Influence of spoil type on afforestation success and natural vegetative recolonization on a surface coal mine in Appalachia, United States. Restoration Ecology, 23(2), 131138.

Shulse, C. D., Semlitsch, R. D., Trauth, K. M., \& Williams, A. D. (2010). Influences of design and landscape placement parameters on amphibian abundance in constructed wetlands. Wetlands, 30(5), 915-928.

Sjögren, P. E. R. (1991). Extinction and isolation gradients in metapopulations: the case of the pool frog (Rana lessonae). Biological Journal of the Linnean society, 42(12), 135-147.

Skelly, D. K., Bolden, S. R., \& Freidenburg, L. K. (2014). Experimental canopy removal enhances diversity of vernal pond amphibians. Ecological Applications, 24(2), 340-345.

Skelly, D. K., Freidenburg, L. K., \& Kiesecker, J. M. (2002). Forest canopy and the performance of larval amphibians. Ecology, 83(4), 983-992.

Skelly, D. K., Halverson, M. A., Freidenburg, L. K., \& Urban, M. C. (2005). Canopy closure and amphibian diversity in forested wetlands. Wetlands Ecology and Management, 13(3), 261-268.

Skousen, J., Zipper, C., Burger, J., Angel, P., \& Barton, C. (2011). Selecting topsoil substitutes for forestry mine soils. The American Society of Mining and Reclamation Proceedings. Sciences Leading to Success. Lexington, KY, 591-609.

Stiles, R. M., Swan, J. W., Klemish, J. L., \& Lannoo, M. J. (2017). Amphibian habitat creation on postindustrial landscapes: a case study in a reclaimed coal strip-mine area. Canadian Journal of Zoology, 95(2), 67-73.

Tiner Jr, R. W. (1984). Wetlands of the United States: current status and recent trends. United States Fish and Wildlife Service.

Tukey, J. W. (1949). Comparing individual means in the analysis of variance. Biometrics, $5(2), 99-114$.

Ultsch, G. R., Bradford, D. F., \& Freda, J. (1999). Physiology: coping with the environment. In McDiarmid R.W. \& Altig R. Tadpoles: The Biology of Anuran Larvae. pp.189-214. Chicago: University of Chicago Press. 
Sanzo, D., \& Hecnar, S. J. (2006). Effects of road de-icing salt $(\mathrm{NaCl})$ on larval wood frogs (Rana sylvatica). Environmental Pollution, 140(2), 247-256.

Snodgrass, J. W., Casey, R. E., Joseph, D., \& Simon, J. A. (2008). Microcosm investigations of stormwater pond sediment toxicity to embryonic and larval amphibians: variation in sensitivity among species. Environmental Pollution, 154(2), 291-297.

Surface Mining Control and Reclamation Act of 1977, 30 U.S.C. 1201-1328 (1977).

USEPA (U.S. Environmental Protection Agency). (2011). A Field-Based Aquatic Life Benchmark for Conductivity in Central Appalachian Streams. EPA/600/R10/023F. Washington, D.C.: National Center for Environmental Assessment, Office of Research and Development, U.S. Environmental Protection Agency.

U.S. Geological Survey, 20140331, NLCD 2011 Land Cover (2011 Edition): U.S. Geological Survey, Sioux Falls, SD.

Vasconcelos, D., \& Calhoun, A. J. (2006). Monitoring created seasonal pools for functional success: a six-year case study of amphibian responses, Sears Island, Maine, USA. Wetlands, 26(4), 992-1003.

Walter, J. A., Neblett, J. C., Atkins, J. W., \& Epstein, H. E. (2017). Regional-and watershed-scale analysis of red spruce habitat in the southeastern United States: implications for future restoration efforts. Plant Ecology, 218(3), 305-316.

Wassens, S., Hall, A., Osborne, W., \& Watts, R. J. (2010). Habitat characteristics predict occupancy patterns of the endangered amphibian Litoria raniformis in flowregulated flood plain wetlands. Austral Ecology, 35(8), 944-955.

White, L. M. (1998). Urban created wetlands as an alternative to urban ponds: an analysis of environmental and economic benefits. [Doctoral dissertation, Oklahoma State University].UMI Company.

Woodward, R. T., \& Wui, Y. S. (2001). The economic value of wetland services: a metaanalysis. Ecological economics, 37(2), 257-270.

Zedler, J. B., \& Kercher, S. (2005). Wetland resources: status, trends, ecosystem services, and restorability. Annu. Rev. Environ. Resour., 30, 39-74.

Zipper, C. E., Burger, J. A., Skousen, J. G., Angel, P. N., Barton, C. D., Davis, V., \& Franklin, J. A. (2011). Restoring forests and associated ecosystem services on Appalachian coal surface mines. Environmental Management, 47(5), 751-765.

Zuur, A., Ieno, E. N., Walker, N., Saveliev, A. A., \& Smith, G. M. (2009). Mixed effects models and extensions in ecology with R. Springer Science \& Business Media. 
VITA

Educational Institutions attended and degrees already awarded

University of Kentucky, Bachelor of Science in Natural Resources and Environmental Science

University of Kentucky, Bachelor of Science in Equine Science and Management

Professional positions held

Environmental Scientist, Kentucky Division of Water

Graduate Teaching Assistant, University of Kentucky

Field/Research Technician, University of University of Kentucky

$\underline{\text { Scholastic and Professional Awards }}$

$\underline{\text { Awards }}$

First Place Ecological Society of America Ecological Restoration Poster Contest, 2019

Forestry and Natural Resource Sciences Graduate Student Award of Excellence, 2019

Best Student Paper Submission, USC Upstate Student Research Journal, 2016

Grants

Graduate Student Conference Travel Award, 2019

Southeast Partners in Amphibian and Reptile Conservation Travel Award, 2019

Graduate Student Conference Travel Award, 2019

Eller and Billings Student Research Award, 2018

Karri Casner Environmental Sciences Fellowship, 2018

Chicago Herpetological Society Graduate Research Award, 2018

Southeast Partners in Amphibian and Reptile Conservation Travel Award, 2018

Graduate Student Conference Travel Award, 2017

University of Kentucky Undergraduate Research Award, 2016

Southeast Partners in Amphibian and Reptile Conservation Travel Award, 2016

Professional publications

Lambert, M. M. (2019). When Bourbon Leaves the Barrel: What Happens to Wildlife When Spills Affect Kentucky's Water Bodies. Land, Air and Water. https://landairwater.me/2020/01/29/when-bourbon-leaves-the-barrel-what-happens-towildlife-when-spills-affect-kentuckys-water-bodies/

Brown M. B., Lambert M. M., Russell A. L., Tuberville T. D., \& Pilgrim M. (2016). Bioaccumulation of ${ }^{137} \mathrm{Cs}$ in Florida Green Watersnakes (Nerodia floridana) from Three Wetlands on the Savannah River Site. USC Upstate Student Research Journal, 9, 19-28.

Russell A. L., Brown M. B., Lambert M. M., Tuberville T. D., \& Pilgrim M. (2016). Mercury Bioaccumulation in Florida Green Watersnakes (Nerodia floridana) Among Three Wetlands on the Savannah River Site. USC Upstate Student Research Journal, 9, 43- 52.

Michaela M. Lambert 